This item was submitted to Loughborough's Research Repository by the author.

Items in Figshare are protected by copyright, with all rights reserved, unless otherwise indicated.

\title{
The mechanism of ketene photolysis
}

PLEASE CITE THE PUBLISHED VERSION

PUBLISHER

(C) Donald E. Thornton

LICENCE

CC BY-NC-ND 4.0

REPOSITORY RECORD

Thornton, Donald E.. 2019. "The Mechanism of Ketene Photolysis". figshare.

https://hdl.handle.net/2134/10874. 


\section{Loughborough University}

This item was submitted to Loughborough University as a PhD thesis by the author and is made available in the Institutional Repository

(https://dspace.lboro.ac.uk/) under the following Creative Commons Licence conditions.

\section{cc) creative}

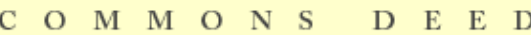

Attribution-NonCommercial-NoDerivs 2.5

You are free:

- to copy, distribute, display, and perform the work

Under the following conditions:

Attribution. You must attribute the work in the manner specified by the author or licensor.

Noncommercial. You may not use this work for commercial purposes.

No Derivative Works. You may not alter, transform, or build upon this work.

- For any reuse or distribution, you must make clear to others the license terms of this work.

- Any of these conditions can be waived if you get permission from the copyright holder.

Your fair use and other rights are in no way affected by the above.

This is a human-readable summary of the Leqal Code (the full license).

Disclaimer 민

For the full text of this licence, please go to: http://creativecommons.org/licenses/by-nc-nd/2.5/ 


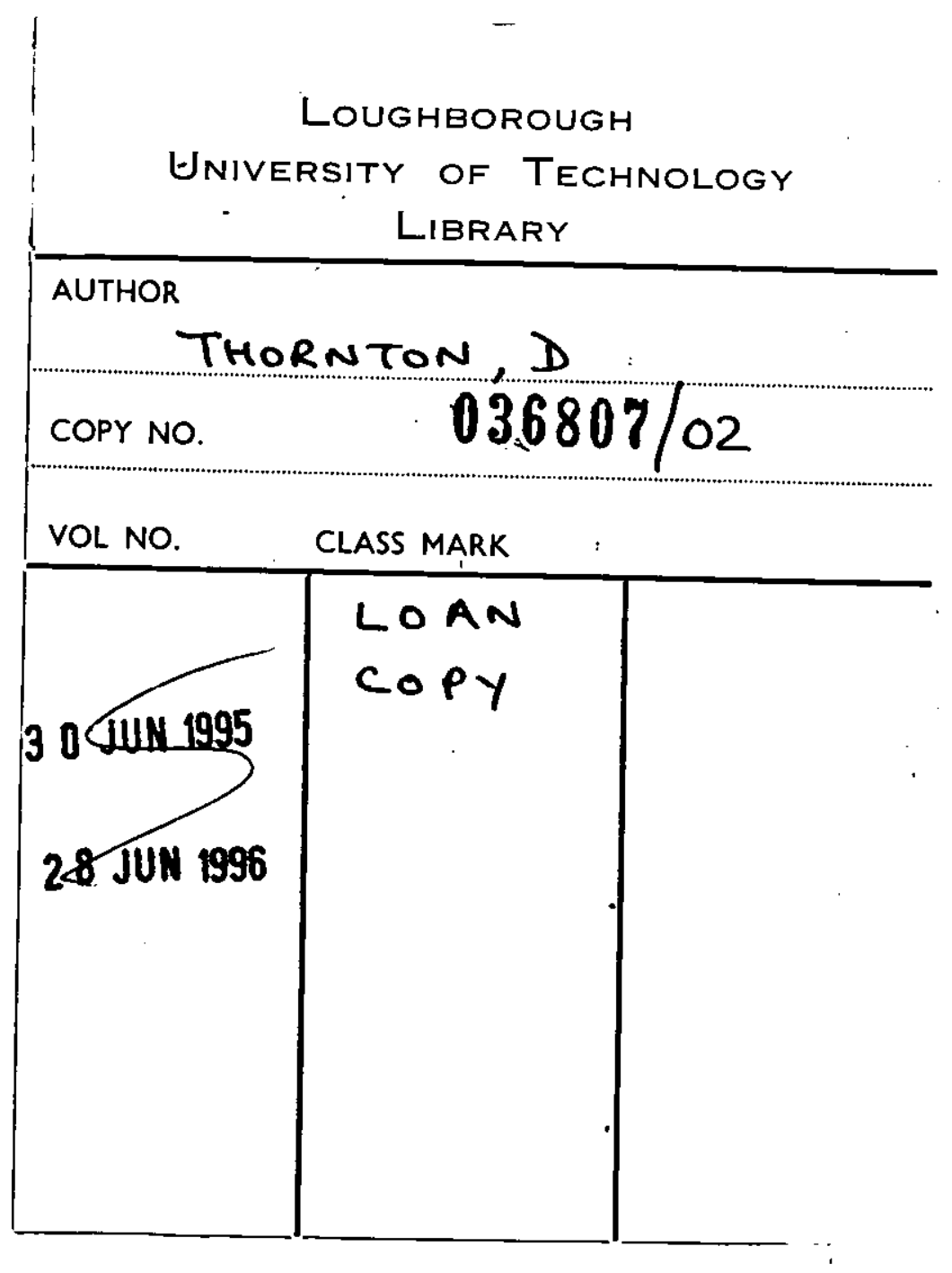


THE MECHANISM OF KETENE PHOTOLYSIS

\author{
A Thesis Submitted to \\ IOUGHBOROUGH UNIVERSITY OF TTECHNOLOGY \\ by
}

Donald. E. Thornton, B. Tech.

Supervisor, Dr. A. N. Strachan.

In Partial Fulfilment, of the Requirements for the Degree of boctor of Philosophy.

September 1967. 


\section{smourx}

Retene has been photolysed both alone and in the presence of inert gases at 3660 and $3230{ }_{\mathrm{A}}$, at varlous temparatures. The wechanis for the photolyals at shortor wevelengtha, around 0 $2700 \mathrm{~A}$, Is fairly otratght forrard beoanse each ketene nolecule that absortos a quantum decomposes and tho oarbon monoxite quanturs Field, cqual to two, 1o independent of tempersture and prossure; At $3130 \mathrm{~A}$ and $3660 \mathrm{~A}_{3}$, horrever, deactivation processes play an 1opurtant part in the photolyole and tho mechentsas are nore conglleatod at those wavelengths. At 3660 A col21sional deeotivation has boen found to bo onomatep procoss, but at $3130 \mathrm{~A}$ this deactivation process becoms two-step, in certain oircumstences. Mechanismo are proposed for leteno photolyels at both these wavelengthr. .

A stmpler mochantign used by prevtous wotkers 10 shosn to bo invelid by 1 to fallure to roconcilo the experimentally astermined rate constants for decomposition, assuming this Dochanisa, Wth thoso celoulated from unimolecular roaction thoory. The new mechant ans proposed inoruto intersystem orossing: :

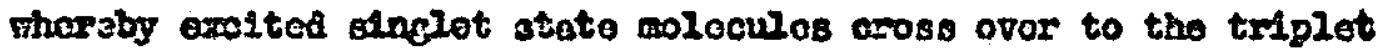
manifold. . Decomosition of both exoited singlot statc and triplot state koteno molecules ocours, reculting in the production of both atnglet and triplat motholeno. These tro motholenos react asperently ith hydrocarbons. Reoent deterainationo, wth keteno - olofin mixtures, of the groportions of olnglet and teiplot nothylene formod are revlewed. 


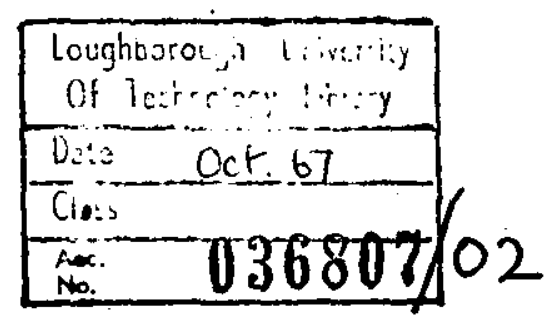


The lack of agreanent botwoun deferent workers and the unoertalnties of the methods are alscussed. An alternative wethod using ketene-cyolopropane alxtures 2a described. Irom the results obtalned by this mothod the proportions of triplet mothylens, at $37^{\circ} \mathrm{C}$, and 2700 and $3230 \mathrm{~A}$ are estianted to be 16 and $44 \%$ respeotively. 


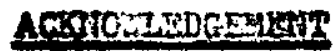

I would Iike to exprose of gratitute to gy euperitsor, Dr A.tF. Streohan, for his guidence ond encouregentent during the lagt threo yearti.

Wy thanks erro due to Hr T. Young for his glasoblowing and his wife, Batty, sor typing tho mamusaript.

Pinully, I must acknowlodgo the seorificeo that wy ife and chilaten have sade to enoble no to carry ont this works this thosis is dedicatos to thew. 


\section{conditise}

\section{Pese}

SOMMARI

1

3

ACENOKTEDGERTHI

6

ImRODUCMION

27

EXFRTIETHAL

28

RESUUTS

Part I

Fant $2 x$

46

Drscussron

63

BIRLIOCRAPH

76 


\section{ILEUSTRATTORS}

\section{Bleuno}

IE

23

38

ID

3D

$\left.\begin{array}{l}40 \\ 50 \\ 60\end{array}\right\}$

$7 D$

8D

gD

200

210
Enolns Page

22

29

25

47

48

54

50

62

73

52

62 


\section{INTRODUCEIOA}

Eset studsee

The first etudies of the action of ultrav10let light

on ketene were ande by Norsieh, Crone and salthereh. 1 They postulated thet the 11ght energy absorbed by the carbonyl group was trensecrsed to thenethylene group with consoquont rupture of the bond.

$$
\mathrm{CB}_{2} \mathrm{CO}+\mathrm{hl} \longrightarrow \mathrm{CH}_{2}+\mathrm{CO}
$$

Fals was followed by the attack of wethylene on kotene.

$$
\mathrm{CH}_{2}+\mathrm{CH}_{2} \mathrm{CO} \longrightarrow \mathrm{C}_{2} \mathrm{H}_{4}+\mathrm{CO}
$$

These wirkers found that the decompostition led to the formation of two volunes of carbon monoxlde to one of ethyleno. Rose and Klatiakowsiky ${ }^{2}$ found the quantus yleld of decomposition to be approxciate $2 \mathrm{y}$ unity at $3130 \mathrm{~A}$. Thoy rejoctod tho secondary reaction of Horrish and hio comorkers because, if thle occurred, the deconposition quantus giold ohould be two. and not unity as found. They ougrested that nothyleno radicals formod in the primary process roacted with each otber to fore - thylene.

$$
\mathrm{CH}_{2}+\mathrm{CB}_{2} \longrightarrow \mathrm{C}_{2} \mathrm{~B}_{4}
$$

At 3660 A they found that the deconposition quantur gleld appeared to be loes than unity.

$$
\text { Norrith and his comorkers old not agroe that the }
$$
observed quantun ylolds necessarily excluded the occurrence of

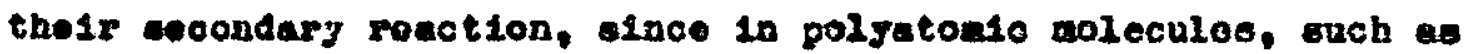

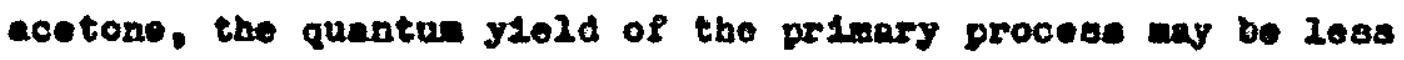
than unity, throughout a conslderable portion of the region of continuove absorption. 
Thus the carbon nonoxide quantua jleldo of lose than tro in ketone photolyolo could be explained by an ineffiolont prinary process, where only a fraction of the excited noleculos decomposed, the rest belng denotivated. 'The fraction docomposing would be expectod to bo lo es at longex uvelengths (10wer energy) and aore at shorter ravelengthe (bigher onorgy). Horrish and hio co-workere clted Ross and klotiakowaky's value of 0.3 . for the decoupositon quantua s101d et $3660^{\circ} \mathrm{A}$, in support of thio explanation.

Later Rlatiakowaky and Mosonborg 4 adnitted that the aecondary reaction proposed by Norrieh ot al. was probably correct. Tivey photolysed ketene in the prosence of ethylone add lound that the ratio of the rates of the formation of ethylene to propsiono remalned unchangod whon tho incident 1ight intensity vas var1od by a factor of four. Propylene lo aleost cortainly forzed by the reaction.

$$
\mathrm{CH}_{2}+\mathrm{C}_{2} \mathrm{H}_{4} \longrightarrow \mathrm{C}_{3} \mathrm{H}_{6}
$$

Now 18 the ethylene forming step is reaction (2)

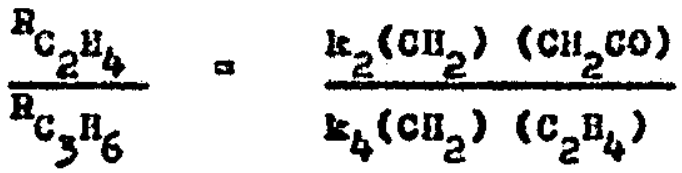

$$
\begin{aligned}
& =\frac{k_{2}\left(\mathrm{CH}_{2} \mathrm{CO}\right)}{\mathrm{k}_{4}\left(\mathrm{C}_{2} \mathrm{~B}_{4}\right)} \text {, and then the ratio } 18
\end{aligned}
$$

Independent of methylono radicel concentration, and honce of the 1nteneity of the indident 11;ht. If ethyzene to torred by the reconbinatson of athylono radicala (reaction (3) ) thon

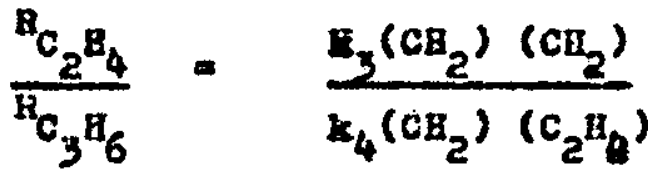

$$
\begin{aligned}
& =\frac{k_{3}\left(\mathrm{Cn}_{2}\right)}{\mathrm{k}_{4}\left(\mathrm{c}_{2} \mathrm{t}_{4}\right)} \quad \text { and the rat10 will }
\end{aligned}
$$

be dependent on tho 128ht intenesty. 
Strachan and lloyes ${ }^{6}$ found carbon monoxido quantud yielde of two at $2700 \mathrm{~A}$ and this is addod confirnation that Horrioh's secondary roaction 18 corroct.

Postulated Mechanisas.

If the two reactions proposed by Borriah ot al wore all thet happenod in the photolysio, then tho carbon wonoxido/ ethyleno ratio should alwaye oqual two. Sho resulto of previous investigations $(1,4,5,6$,$) heve Indicatod that thie ratio is always$ greater than two. Otrechan and loyes ${ }^{6}$ found the ratio to be $2.20 \pm 0.06,1$ in excellent agreomont ith tho value of $2.29 \pm 0.02$ found by Kietiakowaky and Rosenborg. 4 Thlo value appoare to bo conetant over a wide rango of temperaturo, presoure and wavelength.? Strachan and Hoyer came to the conclusion thot this ratio was alwajo eroater than two, becauso sone mothylono formed in the reaction reoults in polywor, efther by ossoclation or further reaction with keteno. It was sugested that $90 \%$ of tho methylenoo forbed at 2700 A rencted with kotono to glve carbon monoxide and ethylone. The remaining 2095 roacted to form carbon monoxide and polymer. Tho reclprocal of the carbon monoxide quantua yleld was found to be indepondont of tomporature and presoure at $2700 \mathrm{~A}$ and the following wechantom was propoced. 6

$$
\begin{aligned}
& \mathrm{CH}_{2} \mathrm{CO}+\mathrm{bH} \longrightarrow \mathrm{CH}_{2}+\mathrm{CO} \\
& 90 \% \mathrm{CH}_{2}+\mathrm{CH}_{2} \mathrm{CO} \longrightarrow \mathrm{C}_{2} \mathrm{H}_{4}+\mathrm{CO} \\
& 20 \mathrm{CH}_{2} \longrightarrow \mathrm{gOIgmor}+\mathrm{CO}
\end{aligned}
$$

At $3660 \mathrm{~A}$ strachan and Hoyeo found that the ploto of tho rociprocal of the carbon monoxide quantum jiold agalnst Letono concentration woro lincar, with postive olopeo and satercepts. 
The alopes decreaced with increase in tenperature, as aid the sntercepts. Tho intercepts docreased frow 13.0 at $26^{\circ} \mathrm{C}$ to 3.9 at $154^{\circ} \mathrm{C}$. The low carbon monoxite qunntum yselds angested thet denotivation procese was taking place and the following mochanian une poetulatod for thlo waveloagthi-

$$
\begin{aligned}
& \mathrm{CH}_{2} \mathrm{CO}+\mathrm{bV} \longrightarrow \mathrm{CH}_{2} \mathrm{CO}^{*} \\
& \mathrm{CH}_{2} \mathrm{CO}^{*}+\mathrm{CH}_{2}+\mathrm{CO} \\
& \mathrm{CH}_{2} \mathrm{CO}^{*}+\mathrm{CH}_{2} \mathrm{CO} \longrightarrow 2 \mathrm{CH}_{2} \mathrm{CO} \\
& \mathrm{CH}_{2} \mathrm{CO}^{\circ} \longrightarrow \mathrm{CH}_{2} \mathrm{CO}
\end{aligned}
$$

With stoady otate aseuggtions the above mechanles $20 a d e$ to the following expreselon for the reolprocal carbon monoxide quantum 51010.

$$
\frac{1}{\sigma_{c 0}}=\frac{1}{2}+\frac{k_{12}}{2 k_{9}}+\frac{k_{20}}{2 k_{9}} \cdot\left(\mathrm{ct}_{2} \mathrm{co}\right)
$$

Fh10, being lineur expreselon with posttivo olope and intercept, accounte for the experimental reaulto. Although no phoophoreccence or Inorescence has been observed from ketene, the Inclusion of reaction (II) 10 necaseary to account for the intercepte not beine equal to $\frac{1}{2}$. whab would be expected if $\mathrm{k} / 2$ wero sero. The decrease in the alopoe and intercepte with Increase of temporcture is explainod if (9) has a andi activation anersy.

The mechaniens proposed by streoban and nloyes ${ }^{6}$ for $2700 \mathrm{~A}$ and $3660 \mathrm{~A}$ formed the base for nechentas ued in 2 ater work. by porter and hie comorkers. $8,20,13$. 
Porter and connaliy ${ }^{8}$ photolyzed kotene at $3130 \stackrel{\circ}{A}$ and 3340 A. Proviously K1stiakowaky and Hahan 9 had found thet

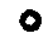
the pribary quantur y101d at $3230 \mathrm{~A}$ was independent of presture, and had subgested a value of unity. This work was dono at low preasures over a narrov range. Porter and Connelly investifated the photolysis at $3230 \AA$ and $3340 \AA$ at preseures up to one atmosphere. when the zec1procal of the primary quantum yleld was plottod againet ketene concentration, ilnes with positivo slopes and intercepts wore obtained. Porter and Connelly deduced from the positive slopes of such plote that collisional doactivetion not only occurrod at $3660 \AA$ but at these waveleagthe too. The Intercopte of those plote appoarad to bo unsty at 3130 A but ereater than unity at $3340 \mathrm{~A}$. The intercepte at $3340 \stackrel{\circ}{\mathrm{A}}$ decreased with increase in temperature. The authors did not rulo out the poso10121ty of the internal convorsion reaction (11) at $3130 \AA$ becauee of the possibl11ty of experimental error. Casoado Derctivation.

Porter and Connel2y $y^{10}$ considered mechanien involving a number of otages in the deactivation of exc1ted kotene molecules. In this mechanisa both elnglet and triplet oxclted otates os ketene vere included, but for Bimplicity the authors onsted the triplet otato in their dotalled calculations conceralng the number of otages in tho collielonal deactivation. The offect of the number of collisione required for deactivation, on the plots of tho reciprocel of the prisary quantum gield 0 , againot keteno concentration we determined. With one-step deactivotion the plote mere Inner but departure eroo I1nearity and lncrease in the quantup yield occurred as the number of atageo in the collielonal deectivation increased. 
Whon thereal Alsaociation of the triplet stoto was inoluded In the mohansen, such plots becane S-shapod. Tho authore thon compared the proposed nechanl sa wth exporimentes reserts. In tho case of cascade Anativation they found ateficulty in couparing experiment with theoxy, becouse of the extra paranster Involving the number of collsalons. The authore conoluded that more preoice exparimental date was required to seo whother the $1 / \not$ T. (ketene) plot extrapolates to a value of less then unity, at 3130 A. A surther invertigation by Porter and Tayior in 1962 exminined keteno photoly als, agaln ot $3130^{\circ} \mathrm{A}$ 0 and $3340 \mathrm{~A}$, et varlous temparatures. Once wore, plots of the reolprood of tho prinary guantum yiold ofuinst koteno concentration zero found to bo Ilnear, and the Intercepts ware always greater then or equal to undty. From prevlous thoory ${ }^{10}$. exy multotage deactivation in tho photolysts would anke these ploto concave upwardis at 20 koteno conoentratione, and the intercepto would bo less than unlty. Forter and geylor thorefore favoured a strong colltalon meohanisn and suggosted that no more than three collibions wero neceseany to degrade an exolted koteno noloculo at 3230 A. In orfer to elmplify thes calouletions, the cuthors assumed that a sinele colliglon was ofleotivo in degrading the molcoulo. E. Energs

If reactions (8) to (1I) ropresent the weohentes of the photolyalis at all wavelengths, wh (10) ano-atep process,

$$
2 / 9=1+\frac{k_{21}}{k_{9}}+\frac{k_{10}}{k_{9}}\left(\mathrm{CH}_{2} \mathrm{CO}\right) .
$$

thare of to the probary quantun giold. 
The inverso olopes of plote of $1 / \%$ againot kotono concentration are therefore oquel to tho decoaposition rato constant $k_{g}$ difided by tho collialonal rato constant $k_{10} k_{10}$ was aseumed by Porter and hio comorkers $8,13,1.3$. to be independent of the oxc1ting waveloagth. Hence, oy plotting tho inverve elopes of the above plote aceinst the energy of tho exciting wavelength. the varlation of the decomposition rate constant, $k_{g}$, with enerey was demonstrated. 8 In a later paper ${ }^{20}$, actual valuos of $\mathrm{k}_{\mathrm{g}}$ woro obtained from tho inverce olopes by setting $k_{10}$ equal to the collision number, with 4 A chocen for tho collision diameter of kotone. The values of the docongosition rato conotant, $k_{9}$, so calculated from experimental data wero compared with theoretical values obtalnod frow the equation,

$$
\mathrm{k}_{9}=V\left(1-\frac{\mathrm{B}_{0}}{\mathrm{E}}\right)^{8-1}
$$

Which is a consequence of the theories of Blater ${ }^{21}$ and Kaesel 12 for unimolocular roactionc.

I Is a mean frequency of vibration of the nolecule and ohourd be $\sim 10^{23} \mathrm{sec}^{-1}$. $E_{0}$ to tho alnimum energy roguirod for decorapooltion, and $B$ io tho total vibrational onergy of the nolecule.

- Io the number of degrees of freedom of tho kotene moleculo. $\nu$. $E_{0}$ and the seromzero onergy of the kotene nolecule are all unlenown. Dalng experinental data at three wavolongtho, porter and Connelly ${ }^{10}$ round that difect calculation of these parametero gave values for then which wore phyolcalis 10posalblo. Howover, reasonable valuco of $V$ and $E_{00}$ tho zero-zero onergy, reproduced the oxperinontal duta within expericontal error. But the authors otated that theory and experinent only agreod qualitatively. If the more complox caos of cascado deactivation considered, there was greater 
affetculty in comparing experiment with theory booquse of the adestional paramotor related to the number of colltatons required for desotiration.

porter and Tayjor, in later work, found linear plots of $2 / \mathcal{D}$ kotine concentration. Thay used the alopes of those plots to calculate values for $\mathrm{kg}_{\mathrm{g}}$ the docomposition rare constant. Ualns those values tho paranoters in the oquation: - $k_{9}=V\left(1-\frac{\mathrm{B}_{\mathrm{o}}}{\mathrm{B}}\right) \cdot-1$ wore calculated for various values, of a. These calculations placed the sero-gero band for kotene at approximstely $4200 \mathrm{~A}\left(24,390 \mathrm{~cm}^{-1}\right)$ whtoh elthough It cannot be checked atreot2y, does correspond to the lang wavolength Iimit of ketene absorption. Thore aro affeloulties In comparing theoretical and exporimontal values of $\mathrm{k}^{\circ}$ the decomposition rato oonstant, and only qualitative agreoment has been eoktered.

\section{Intersoteten Crosging}

In oarlier celculations showing the varlation of $k_{9}$ wth enerey. Forter and Connol2 $y^{8}$ ald not include triplot states in the postulated meohanisa. Tho pesslbiltty of the contribution of teiplet states to the alsuoviation process was mentioned by theae authora; In their lator wark, ${ }^{20}$ these authors ald include intor syotem orosaing in thoir detalled mochanion. In tho thooretioal plots of $V / \$$ primary v. koteno consentration that wero

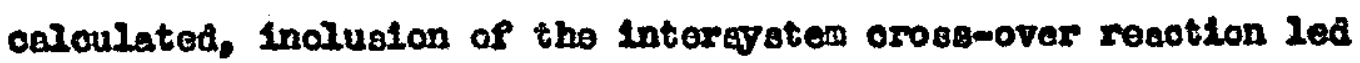
to S-shaped curves. Bxperimentally suoh ploto wero elways found to bo 2 inear and henco tho cross-ovor reaction was exoluded. 
Althougb 2lnoar plots rulo out tho posolbility of intorogotem oroosing frod the lowest vibrational zevolo of the exoited siaglot stato, this reaction pothway could occur froa the higher vibeational levelo of the exoltod olngiet otato.

The olfaticance of tho intoroyoton erosomover recotion has beon esphastzed, by Hoyed and 0uger ${ }^{34}$, as one of tho ajor pathwayo in photochecteal reactiono. Theoe authors ougceated that in ketene photolyole at $\$ 660^{\circ}$ a nang of the excited coloculoo croos over to the triplet otate.

$$
{ }^{1} \mathrm{Cn}_{2} \mathrm{CO}(+\mathrm{n}) \longrightarrow{ }^{3} \mathrm{CB}_{2} \mathrm{CO}(0 \mathrm{H})
$$

Tho authore ougeost that tho compoting procosend vould bo

$$
\begin{aligned}
& { }^{1} \mathrm{CH}_{2} \mathrm{CO}+\mathrm{H} \longrightarrow{ }^{1} \mathrm{CH}_{2} \mathrm{CO}_{0}+\mathrm{n} \\
& { }^{1} \mathrm{CH}_{2} \mathrm{CO}_{\mathrm{n}} \longrightarrow \text { producta. } \\
& { }^{1} \mathrm{CH}_{2} \mathrm{CO}_{\mathrm{O}}(+\mathrm{H}) \rightarrow{ }^{3} \mathrm{CH}_{2} \mathrm{CO}(+\mathrm{N})
\end{aligned}
$$

Wot enough is known to dectido whother collfeione would be rate detemining in the crood over reactiono or not. In conclusion the authors atated that the agparent effect of collialone la onhanelag the nubber of triplot mothyloner ong Do duo to an effect in promoting crosis over of exaglot to dplet ketene, rathor shan in prowoting crossovor from alnglet netiylene to triplet nothyleno. It wao sugeosted that in the wavoleneth region $3000 \mathrm{~A}-3700 \mathrm{~A}$. where diecociation 161080 rapid than at oborter savelengths, excitod olnclot noloculec. foried in the obaopption act, calnly oroso ovor to the triplet stato. 
Whother 1t 10 an excitod precursor or wethyleno 1 toolf thet undergoed olnulet triplet tranostione, collialone apgear to play an ingortant part in such tranoitions in other syotens. Anet and hio comorisere ${ }^{15}$ and Frey ${ }^{16}$ photolyoed diagonethane In the prosence of cisbuteno-2 and an inert gad. Hersbers had oboun previouely thot a high ratio of lnert gas to diaconothane vao necossary to produce triplot cothylene ${ }^{17}$. and Indeod Froy ohosed that tho products due to the reactions of triplet cothgiono increasod as tho ratio of argon (the Inort Eas) to olobuteno-2 was incroaed. Froy pointed out thet anet ot al did not work at oufficientiy high prosaures to prevent the geomotrical loomerication of the vibrationaliy excitod c10 1.2. dimothyl cyclopropano, which was produced by the attack of aethyleno on the c1s butene-2. It beems, therefore, that collialone play some part in the interayeten croseing reaction in tisio syotem but whother it is excitod diaronothane moleculoo or wethylenos thonosives thet undergo thio reaction 10 uncortain.

Gumary

Threo nain problens etrerge fron the studies of tho photolyolo of lotene. Mrstly thero 10 otlll ooro doubt ao to whother deactivation, in the $3000-3700$ a region of tho photolyalo, 1o one-step or mult1-stop. Seconaly comparioono Detween experi.ontal data for the rato constanto of decoopoution add the rate conotanto calculatod fron unloolecular reaction thoory of kabuel and Slater have not been too succeosful. 
Third2g. there is uncertalnty as to the extent of the intoreyston crosolng roaction and tho proportiono of olnglot and triplet mothylenes produced in the photolyo10.

The pesent studies vere otered uth the object of trging to resolvo ouse of those probless. Inert gases trere uoed in the photolyois at both 3660 and 3130 A. It was hoped that by conparioon of tholr deactivation efficiencies uth that of ketene, sone more information on the deactivation procesces in tho photolyeio would be obtained. The polyweriantion of ketene accelerates ae tho peessure of ketene increasoo, and on alternate way of obtaiaing higher presouros in the syoten to to use a snall conotant anount of ketone wth increasing anounts of inart cas.

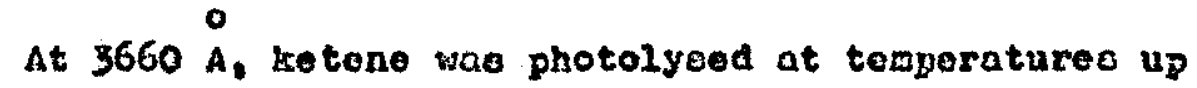
to $300^{\circ} \mathrm{C}$ in order to obtain more information on the rapid chango of $\mathrm{k}_{9}$. with temperature, at thle wavelength. DLecrepanciea in tho value of $\mathrm{k}_{\mathrm{g}}$ at $.3230 \mathrm{~A}$, in previoue work. 10,13. and sone doubt as to the variation of the recifrooal primary quantuo yielde 8,9 . at 10 preseurea, propptod the ceasurewent of quantur ytelds at 3130 A.

It 18 bolloved that only ofuglet nothylene undergoos tho insertion reaction with $\mathrm{C}$ - Il bondo, and therefore by photolyaing betene in tho probence of exceas cyclopropano, It was hoped thot olnglet pethylene would all ronct with tho bydrocarbon, wislet tho triplet would react with keteno to of vo ethylene and carbon monoxide. From the carbon monoxide/ethylone ratios an dotimate of the proportiono of ainglet and triplet Dothyleno in tho photolyels coula be made. 


\section{EXPERIAETITAL}

Matorialo

Sotene was prepered on a vacuun line by pyrolyzing acetic enhydrido. 18 Acetic anhydrido was allowed to pass through furnace, arintalnod at $500^{\circ} \mathrm{C}$, and the producto from the pyrolyelo wore condensed in throe cold traps. She firet and second traps, of dry 100 and acotono, at $-78^{\circ} \mathrm{C}$, condensed acotic acid and any undecomposed acotic anhydrite. Tho third trap of 11quid altrogen, at $-196^{\circ} \mathrm{C}$, condensed the ketone. Frep to trap aletillationo were perforaed on the frobhy propared ketono to ronovo any uncondengables. The keteno was then froson down into a detachablo bulb, which was kept under Itquid aitrogon at all timeo, to provent polymorioation. Octalluoro Crclobutane (Froon-C-318) wao the product of tho Matheson Company and wo otated to be $99.99 \%$ pure. The gao was always thoroughly degassed, at tho tomporaturo of I1quid altrogen, prior to each run.

Julphur fierafluoride was the product of the fiathoson Coagany and otatod to be $98 \%$ pure. Frior to each run 2t was degacsed in tho bamo way as tho octafluorocyclobutane.

Cyclopropane and Propylone were both producto of tho Hathocon Company, and otated to be of $99 \%$ purity. Those gasos were degasood thoroughly beforo oach run.

Carbon Fonoxide. Ethylone. Hethane, and Ethano wero all obtalned fron the Hational Chenical Laboratory, Teddington, 514ddlogex, The gaseo wero In 500ml. bulbo, at atroogheric prosoure, which tore soalod under vacuum. 
The purit1es of the gases were etated to be as follows:-

$\begin{array}{ll}\mathrm{CO} & 99.96 \% \\ \mathrm{C}_{2} \mathrm{~B}_{4} & 99.92 \% \\ \mathrm{CH}_{4} & 99.62 \% \\ \mathrm{C}_{2} \mathrm{H}_{6} & 99.90 \%\end{array}$

These gaces were atteched to the vacuun 21ne, and used ao otandarts for the chromatographle work.

Diethrl getone was a product of British Drug nouseo, Poole, Encland. It was otated that 95: of tho ketone boilod botween $99^{\circ} \mathrm{C}$ and $104^{\circ} \mathrm{C}$. The ketone was distillod on a Fodd coluan, and a midalo fraction, boll1ne at a constant $102.5^{\circ} \mathrm{C}$ was collected. This was stored tepporarily over anhydroub copper oulphete. The sulphate ald not indicate the presence of water. A portion of the ketono wes thoroughly degaseed on the vacuum line and subjocted to several trap to trap diatlizatione, the midde third beind callected in a detachablo bulo, whero it was otored under ilquid nitrogen. Lipht Dource and Filtere For the work at $3660 \stackrel{\circ}{A}$, the 11ght sourco was a Fh1llps black Glabo worcury vapour laap (H.P.H. 225 batte).

For 3130 and shorter wavelengtho, a llanovia high preopure nercury aro bap (Iypo U.V.S. 220) was used. A ton conticotro focal longth quarto 10no, and an operture in tho lanp bouding, woro ouflicient to produce $\mathrm{g}$ falply uniford and parallol 11.ht bean. Noutral conelty filtero (Bapr and stroud Ltd., Glaggow H.3)., were used to varg the intenoity. The ilter combinations uood to ioolate difforent wavelongth regtono aro 110 ted in soble 1, and theis tranomiogion properties are shown in Flgure 2E. Hecourecente wero made with olthor a IIIloer tatto Uviopec or a Unican 0.P. 700 recoraing spectrophotoceter. 


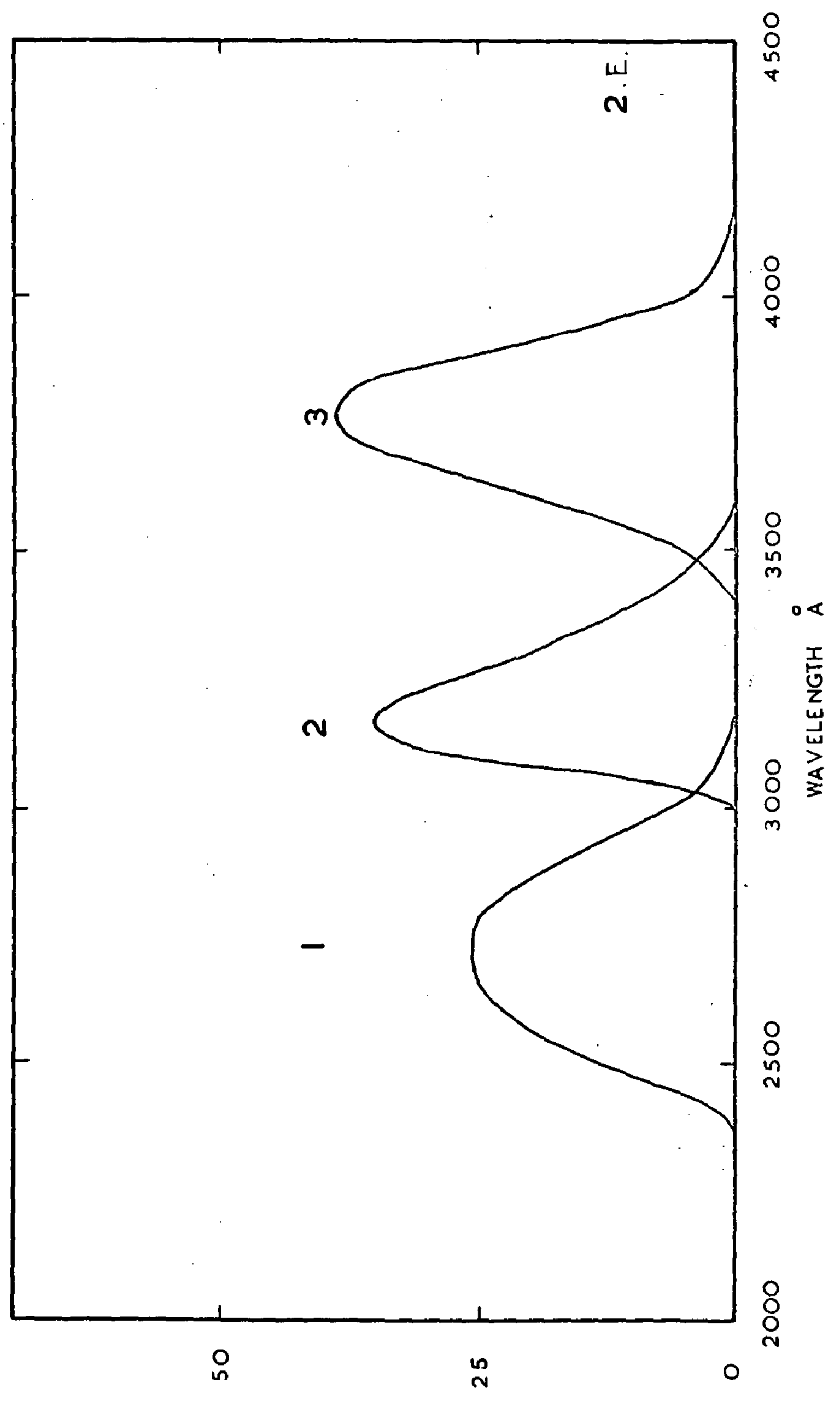

NOISSIWSNZYI o/ 


\section{8: I}

Iiter combinations usedi-

1. Corning Giase 9863

(Red Puxple Corex A)

Thicloneas 3men

$30 / 200 \mathrm{ar}$

20 ag/100-2

Iranemte $2300 \AA-4200 \AA$

$$
\text { - }
$$

$2700 \wedge \&$ Iranead cestan $=70$ 0

3130 A g Trensmisaton $=87$

3660 A gr manamisaton - 62

$\mathrm{NASO}_{4} \mathrm{CH}_{2} \mathrm{O}$

(an) Lodtae

5om pathrength. 2om, pothrongth.

2. $\mathrm{MACl}_{2} 6 \mathrm{H}_{2} \mathrm{O}$

$4.232 \mathrm{~g} / 200 \mathrm{~m}$.

50w. pathlength.
$\mathrm{K}_{2} \mathrm{CrO}_{4}$

$0.01218 / 200 \mathrm{n}$.

20m. pathlength 20n. pathlength

+ Corning Glane 9863

3. Chanos Plulington pistera

$$
\text { O.V.I. (Purplo) and 0.X.I. (Untraviolet) }
$$

Alckel sulpirato hexinydrate, ntokel obloride

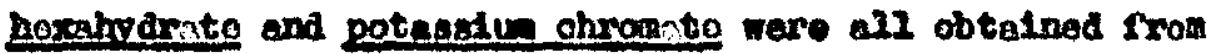
Fopitins and MLIILams Ista., Chodrell Heoth, Ragex, as Analar exades,

\section{Potesulum hudrogen phthlate was obtoined fron}

Hopline and Fil2liams Lta., and otated to be $99.5 \%$ plto.

(on) lodsal (2,7 - almothyl - 3,6 - Alasooyolohopt

- 1,6 - atene 10alde). The preparation of the coxrenponatng porohlorate (Cation $X$ ) is described by Sohrrenbeoh end Luts ${ }^{19}$. The lodide cen be prepared by the same nothod using byartodic acid in place of perchloric, if the quantity of water added in the final stege is reduced. 7 The propertios of most of these flitere are describod in dotell by Feaha. 20 Eliter combination 2 has been described thut and Dav1s. 21 
All tho fllters used were found to bo stablo to prolonged expoeure to ultreviolet 11ght, oxcopt for potassium boarogen phthalate. After ono of two weelso of use, a mould atarted groing in this colution. Therepore when 11ght in the $3130 \mathrm{~A}$ rogion was used, this colution was ohanged every woek. Tho ultraplolot spootrua of kotene 10 shown in

Pigure 1E. A I0am. gas coll was elliod with keteno to a prosarro

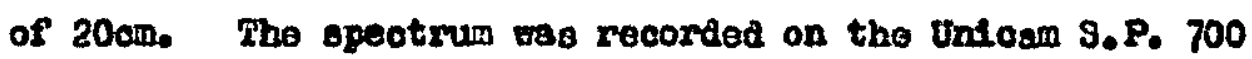
spectrophotomoter.

Apparatus

The apparatus was of conventianal high vacurn design. A good vacuun was obtainod ustag a morcury diffuel on pump beaked by a rotary high vecum pump(Batrards speediveo). Tho roaction vessel was a cylinarical quarts cell, 200n, in 1 angth and 3,00m.

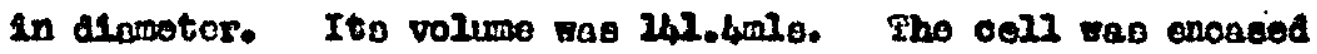
In en elumintim jookot and hoated eleotricaly through o varieo control: It ras vell insurated with acbestos papor and good temperature control $\left(+0.5^{\circ} \mathrm{C}\right)$ was obtulned from $37^{\circ} \mathrm{C}$ to $300^{\circ} \mathrm{C}$. At the lowost temperature user, $\left(3 T^{\circ} \mathrm{C}\right)$, better temerature control was obtained by incorporating a $10 \mathrm{H} . \mathrm{F} . \mathrm{D}$. condensor in the variac osroust.

A small Pingor, at tho far end of tho reaction cell, Impersed in liquid nitrogen, was the means of trangforring ceseo Into the cell. For the 20 prossure runs of kotenc and koteno with Inert essed, the contents of the coll wero thoroughiy mixed by noans of a 250m, bulb, fliled atth worcury, and atteched to the tubo 2cading into the coll. 


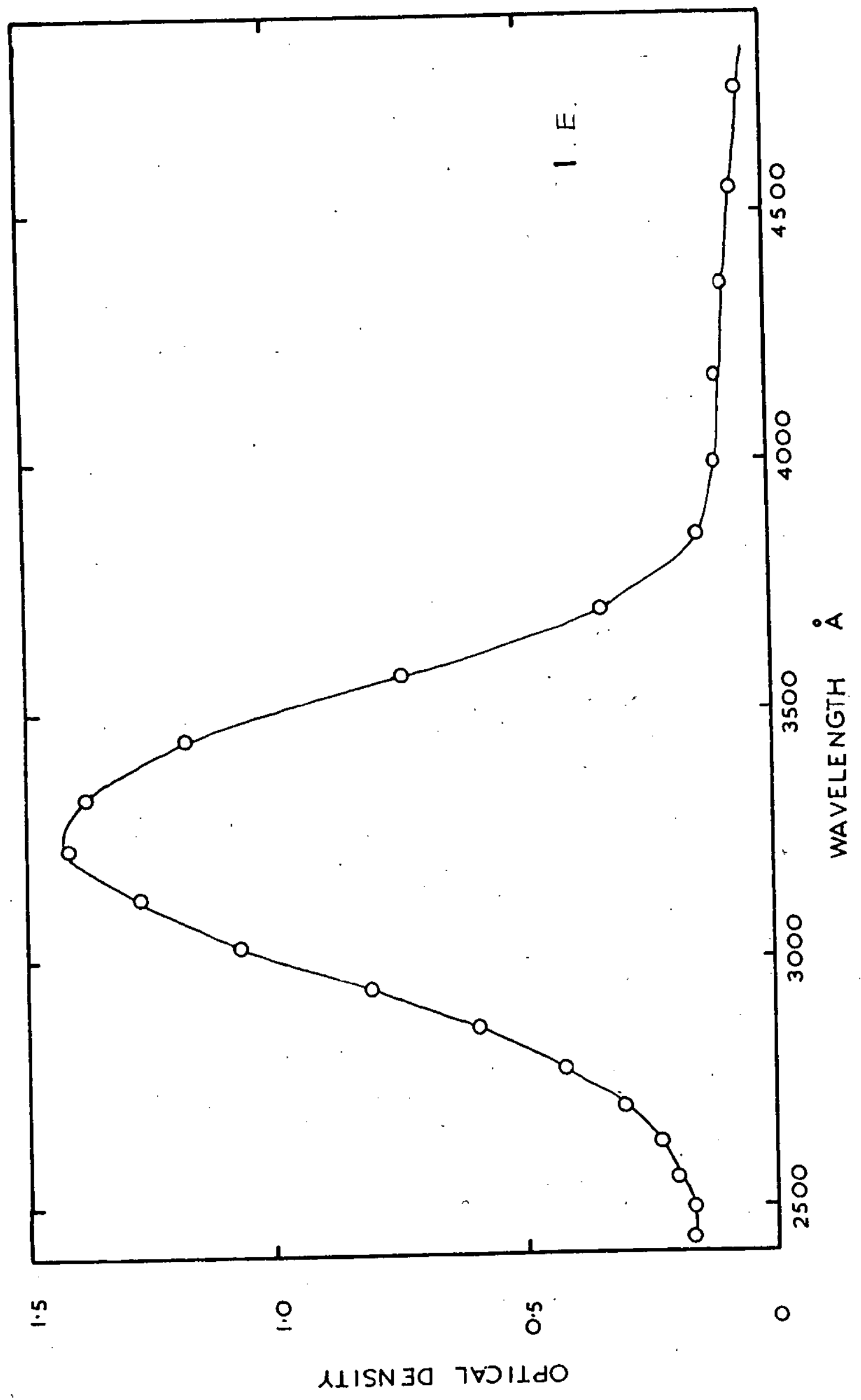


By. rolging and lowering the morcury in this bulb, tho gases in tho cell. were alternately compressed and expanded. Ten or so. expanstong gave good mothg. Tho meroury, was then ratsod, and a mercury sloat valvo soalea tho cell and its contents. In high prossuro muns with inert gases and in all runs with cyolopropano and propylene, tho gasos wero wred by raptd ovaporation from $-196^{\circ} \mathrm{C}$ and allowing, tho coll contents to otand for $15-20$ minutes. before the start of each run.

The flrgt eorlos of runs constistod of photolyaing koteno alone and koteno with Inort gases, ayclo- $C_{4}{ }^{8}$ and $896^{\circ}$ For those runs the only produot sesaured we carbon monoxde. This was, dono on $a$ combined Holeod gauge - Tooplor pump. 6

In tho second serios of runs, in whion koteno was photolysed in tho presence of ayolopropane, or propylene, both carbon monoxldo anẹ ethylene wero messurod. Carbon monoizldo analysis const sted of purping the gas into the Holood gauge - Tooplor purp and aeaguring it quantstatively. Thon the gao was put through a chromatograph. Ethyleno, was only meanurod obronatographtoally. The Instrument used for chromatographio anelysos was a shantion R.G.2. Thornocell chromatograph. This was nun at a tomporature of $31^{\circ} \mathrm{C}$. Argon was the carrior gas and the 810 rate was $6.0 \mathrm{ml} . /$ min. Fion tubing $\left(\frac{3 n}{16}\right.$ outsido disneter) wo usod for tho colum and also for tho comnootlons from the instrument to tho vacum 14ne. Tho coluran packing material mas Poridn Elmor Part lio, DE, 124. Tho 14quid phase wa blom-2wothosyethyl adpsto +al-2- othylhoxl sobacate. Tho support was chromasorb $P($ mosh af $8060-80)$. Amounts of those constituentis wero $23^{2}, 61: 80 \mathrm{vt} . / \mathrm{wt}$, , respectively. The colum was 25 feot in length and was capeble of separating ethilono from cyolopropano(or propyzene) and from any ketane present. 
This colunn would not separate carbon-monosde frem mothens or othoIene from ethane. However for runs were dano using a silver nitrate/othelene sigool colvan. Tris columen woula not offeot a comploto soparation of mothane from carton monoydio or othene from otholene, However distinctive shoulders, duo to mothane and othane, fild show on the oaxbon monoxide and othylene peaks, when small ands of $\mathrm{Cl}_{4}$ end $\mathrm{C}_{2} \mathrm{H}_{6}$ wero injeoted with sluse of $\mathrm{CO}$ and $\mathrm{C}_{2} \mathrm{H}_{4}$ reapectively. Anslyaing a run at $3130 \mathrm{~A}$, small shoulders wero soon on tho $\mathrm{CO}$ on $\mathrm{C}_{2} \mathrm{H}_{4}$ peaks but it was estimated that the $\mathrm{CH}_{4}$ and $\mathrm{C}_{2} \mathrm{H}_{6}$ constituted approximate2y 5-10\% of the masn produotis, CO and $C_{2} \mathrm{~B}_{4}$. In all Later runs, using the ester columb, ondy 60 and $\mathrm{C}_{2} \mathrm{n}$ wero meneurod.

\section{Expexirentel Procedume}

Bxporimentsl grocedure can be convententis divided into tso parts:

(1). Rune pith koteno alone and keteno with inert gasos, and

(2). Rune with betene elone and kotene with hydrocarbons..

(1). Rotene alono and ketone ab th inent kases.

Por each run, a small quantity of kotene was removed from the otorage bulb and degassed three thines at the teaporature of Ilqua nitrogen, A known pressure was allowed to ftil the oell. In 20 prossure runs the pressure of the coll contents. could be wessured alreot2s using the mercury-fliled wizing bulb, atteohed to tho coll, At higher prossures, the quentities of ketene were wabured in a known valume of the vacurm 21 no, by means of an on-2lne meroury manometor. 
The 648 was then condensed 2 to tho 0021 and the pressure in the cell was caloulated. Bor runs in which an inort gos was used, tho quantity of lnort goo was pensured in a sladlor way, and then condensed into the cell. Sulphur haxafluoride and ootafluorocyclobutano were kept in two 11 tro storage bulbs, attached afreotly to the vacuus Ilne. At the end of oach run, the gasos in the 0011 were allowed to pase through two cold traps. Tho first wes at $-296^{\circ} \mathrm{C}$ and tho second at $-220^{\circ} \mathrm{C}$. The $-220^{\circ} \mathrm{C}$ trap was sohteved by pumping on froshly prepared Uguta nitrogen for at least trenty minutes. The temperature of this trap could bo measured by a copper-constanten therapoouple connected to a Fye theraocouplo testsot. These trape condensed all products and reactants oxoept carbon monoxite. Fhto gas was pumped into tho combiried Hotood 8qugo - Tooplor pupp and measured guantitatively. Canverstono wero kopt <2\%.

(2). Iotene alone eni ketene with waroosions

For all runs, quantitios of keteno and bodrocarbon wore moseured in e knom Isne volume by the mercury manometer, and then condensed into the reaction oell. The hydrocarbons rero taken airectly from their cylinders end thoroughly degassed by soveral trap to trap alot2uletions before ecoh run. At the end of each mun a equll freotion of the reaction cell'B contents was isolated. This wos cohieved by having a gall, known, volume next to the resotion coll. By opening the coll, allowing the coll contents to 8121 this mall volume and wating unth equilibrium as estebliahed, known pereentage of the totel neaction mixture was isolated. 
In oblculating the percentage this represented, account wat taken of the difference in tergerature botween the cell and this ongll rolune. The reasons for this procedure rere trofold:Biratly it allowed duplloute analyses of each run to be perforiad. Beconaly, only gall alugs of the ethylene fraction could be Injeoted into the chromatograph beceuse of the low carrier gae Mow rate. If tho pressure of the geses to bo injected becano ogual to ar excested the carrier gao presaure, then the alue would not be injeated oleanly. This could oause back pressure, resulting in 20nE drawn out, mis-shapen, poaks. When tho anall fraotion of the ooll contente had been 2 solatod, it we condensed over coda abestos (fioplins ond of the undeospposed ketene. Stopeock A (see Iigure 3. B. ) was olosed and the gases more then allowod to pass through trapa at $-196^{\circ} \mathrm{C}$ and $-210^{\circ} \mathrm{C}$. These trope removed all resotants and produots expept cexton conoxtde and any mothane. Sho oerbon monoxide Praotion was pumped into tho Itoleod gaugo - Toopler pura end 1to pressuro and volumo measured. After tho the carbon monoxdde Ereotion was traniferred to the injootion loop for chronatographio onalyals. The procedure for doing this was os follawo:The morcury in the MoLeod gango - Toeplor pump was lowered to jugt below point B. (see Bigure 3.B.). Stopooct B was closed and the loop, which had been ovacusted through $D_{0} C$ and the high vooum 14no, vas oponed through $D$ and $C$ to Iooplor II. Tho mercury in Toepler II was lowered and tho meroury float valves at G ani $\mathrm{Al}$ vero freod. This allowed freo pasace of the corton monoxide frooction from I, through If, to the 20bp. 


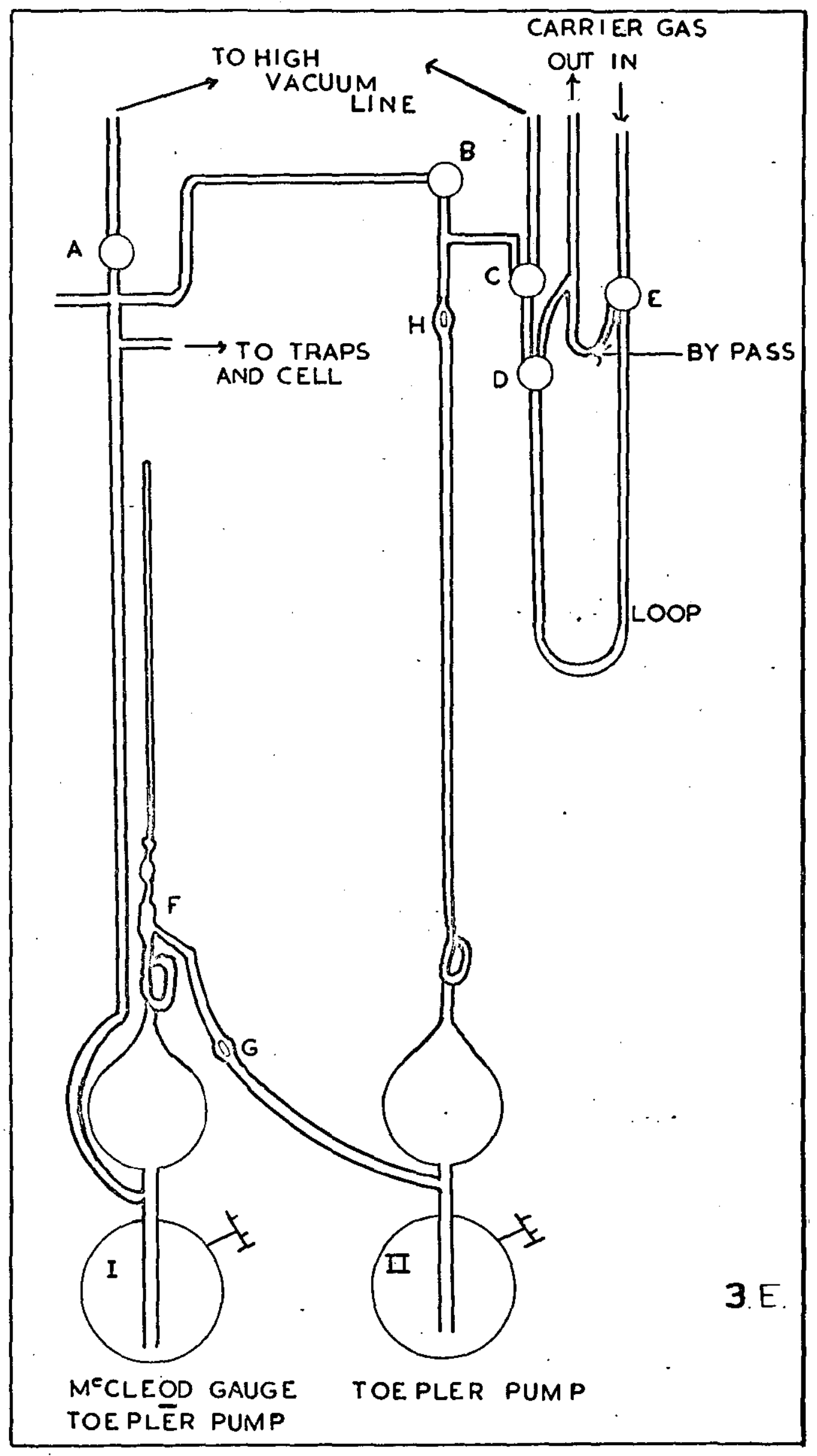


2his cas frotion was then trangerred quantitatively fran I to

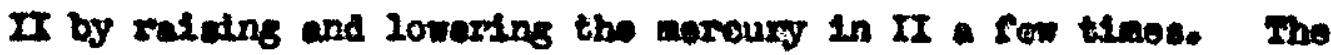
eoroung in II we then reised to $H$ and the Co fraotion. fliled the Loop and the anall dead - space Botween D, B and H. Stopoook D. was turned ore. D was openod end the gas in the dead-apace was punpad back into $I$, and Its voluen and pressure weacured. This was between 30 and $40 \%$ of the total gas firat seneured. During this acquance of operations the currilar gas was Rowng into $\mathrm{B}$. along the by-pass and back to the chrountograph, The carbon monoxdde fraotion was injected by turning $I$ and $D$ eliwitaneously, so thet the onrrior cas sinept the contents of the $200 p$ into the chroustograph.

The next stage in the procedure was the introptuotion of the etbylene fraction, wioh contalned etiolene, cyolopropane, a mall enount of ketene, and any othane, into the ohromatograph. The cold traps were renoved and the condensed gases evaporated into the closed line (A alosed). Ine gases wero condensed into the Injootion loop trimough $B, C$ and $D$, by placing a Nack of 2Aquid attrogen axount the loop. Whon ail the gases mere condensed Into the 200p. D vas turned ofe and the 21 quid nitrogen renoved from the 200p. When the gakes had reached soco temperature, injeotion of this etholene fraotion was performed in the sone why as for the carbon annoxide fraotion. Dup21cato anclyses roro pexforand in this eocond eeries of runs.

\section{Quntur yela deteminationg.}

Quentus giolde wore doteminod in two welength reglons centred around $3660 \stackrel{\circ}{\mathrm{A}}$ and $3230 \stackrel{\circ}{\mathrm{A}}$. 
Light Intemaltios wero anacured before; during and after coob zun by means of a vacuram photocell(Type Q.V.A.39). The photocoll ras conneoted in series with a 120 rolt hlgb tanolon bettery (Ever Read Finner) and a D.C. alaroaneter (Pyo Sonlarp). The

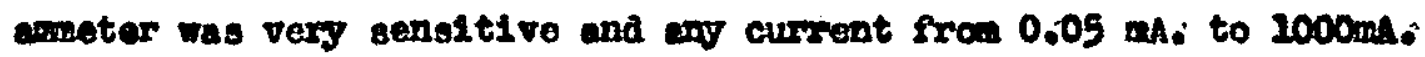
could be racd acourately; Hgint intenglties masured this way; before and aftor each run were avexaged to give $I_{0}$ values:

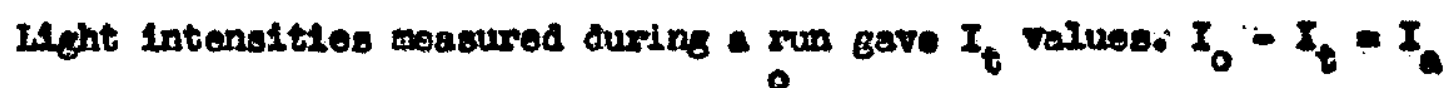
(the intensity absorted): At 3660 A relative guantum yielos only wre wessured. The ebsolute magnitudes of the reolprocel quantum glelds at $3660 \mathrm{~A}$ wre based on tho velues obtelned at the vevelength by Portor and Taplor ${ }^{33}$, at $23^{\circ} \mathrm{C}$, using a forchoxalate notinomotax. For a plot of the reciprocal of the prinary guantur Field against kotene conocntration they found an ioverse lopo of $4.029 \times 10^{-5}$ mole $14 t \times 0^{-1}$. Uakne this relue, and sesvilng the inverse alope inoresces wh thenature with an cotivation enores of 4.5 koal. wole $e^{-3}, 6$ tho inveres alope at $37^{\circ} \mathrm{C}$ was calculated to be $5.697 \times 10^{-5}$ molo 21 tre ${ }^{-2}$. The was then compared to the inverse lope neasured in this work at $37^{\circ} \mathrm{C}$, in terses of a mlcroanneter

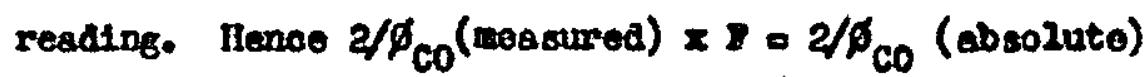
end I was found to be $30.09 \times 10^{-6}$. All the $2 / \phi_{C 0}$ values which were deanured at 3660 A wore multiplied by $F$ to obtain aboolute values.

Bor guantus rieid doteruinations at $3130 \stackrel{\circ}{\mathrm{A}}$ diethy 2 ketono was used as an internal actinomoter. Aotinonster runs rewe ado st $200^{\circ} \mathrm{C}$ and botono proseures enployed wero around 2.000, Tho carbon monodide quantun ylelt, under these canaltions has been shom to bo unt ty. 22 
Standaralsetion of the chromatosamph.

A mall amount of caxbon manodide wo taken fron the eatiplo bulb attached to the vecuma 2ine, and pusped into the Hoteod gauge - Toepler pung ( I. Plgure 3. Bं). Its preseure ana volume were acacurot. The teroury in $I$ was then lowered and the meroury thread broken at $D$. trapplins the carbon wonoxide in the BoLeod geuge. A emall quentity of othylene was then pumped from

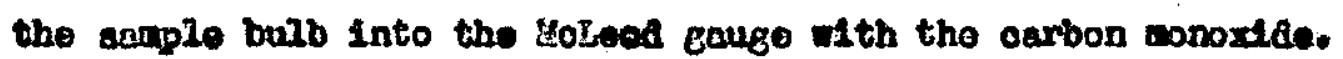
The total pressure and polume were then messured. Bros these moasurements the numbers of moles of carbon monoxide and ethyleno in the nixture wore oolculated. The atxture was than treneferred Vla Toepler II to the loop. The Bases ware allored to equilibrato In the $100 \mathrm{p}$ and the deadspeco $\mathrm{D}, \mathrm{B}$ and $\mathrm{H}$. Stopeock D was turned off ond the mixture romalning in the deadspace ves pumed book to Hotiod I and reneasured. Tho slug, of known anounts of carbon monoxlde and etlyiene, was then injeoted and tho arcas of tho carbon monodide and etboleno peaks measured. Tho area/mole for both gases was worked out, and also the ratio $\left(\frac{\text { atholeno area/mole }}{\text { carbon nonoxido area/nolo) }}\right.$. whioh gave the relative senstififity of the instrument to theso two 8ases. This procedure was dano a for times and reproduclblo resuits for the rolative sensitivity, at varlous ohromatograph sensitivitios, wero obtained. The average of these results was oaloulated to bo 1.868, and in the second serles of zuns, kotano with hodrooarbons, the (area carbon monoxide) ratio was mutiplied by this faotor to got true carbon monoxda/othylene ratios. 


\section{RASULFS}

Tablea 4 - I shot values of $2 / g_{\text {co }}$ at varlous ketono and Inert sas concentretions at 3660 A, $3130 \AA$ and various temperatures. At certaln ketene conoentrations in mabled

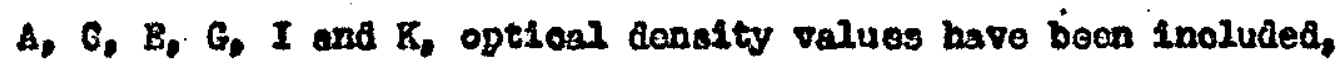
and these $\mathbf{0} 211$ bo used later to oonstmot Beers Lam plots. 


\section{TABLB $A$}

$3660^{\circ} \mathrm{A} \quad 37^{\circ} \mathrm{C}$

\section{gripans ALOAS}

\begin{tabular}{|c|c|c|}
\hline (x) Morus/twWRB $=10^{3}$ & OPPICAL DEHSIIYY & $2 / 8 c 0$ \\
\hline 3.16 & 0.280 & 59.6 \\
\hline 5.39 & 0.350 & 103.6 \\
\hline 5.90 & 0.336 & 228.2 \\
\hline 8.18 & 0.482 & 214.9 \\
\hline 9.96 & 0.578 & 180.4 \\
\hline 3.62 & 0.216 & 76.4 \\
\hline 15.03 & 0.875 & 304.7 \\
\hline 20.32 & & 386.3 \\
\hline 2.67 & 0.265 & 72.8 \\
\hline 2.17 & & 73.2 \\
\hline 1.76 & & 62.0 \\
\hline 2.38 & & 54.2 \\
\hline 0.52 & & 33.4 \\
\hline 2.16 & & 48.2 \\
\hline 2.35 & & 45.8 \\
\hline
\end{tabular}

(R) Is ketene conoentration. 


\section{TABLB $B$ \\ $3660 \AA \quad 37^{\circ} \mathrm{C}$

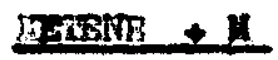

(K) $=2.52 \quad$ moled/11tro $\times 10^{3}$

(ti) MOLES/LITRE $\times 20^{3}$

$7=C_{4}^{8} 8$

21.78

529.2
326.6
464.4
201.8
272.2
94.4
$4=85_{6}$

11.23

261.3

27.59

398.0

U4.43

334.5

21.34

470.0

4.81

167.8

3.03

242.5

13.43

328.7

(x) Is kotone concentrotion.

(if) Is Inert eas concentration. 


\section{NABLB G}

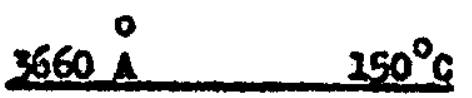

\section{PEZRZN ALONB}

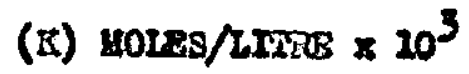

OPRICAL DAMSIAY

$2 / \phi_{C O}$

$$
\begin{gathered}
2.02 \\
4.21 \\
7.60 \\
11.49 \\
24.88 \\
0.92
\end{gathered}
$$

$$
\begin{aligned}
& 0.228 \\
& 0.407 \\
& 0.684 \\
& 0.994 \\
& 1.222 \\
& 0.079
\end{aligned}
$$$$
9.0
$$$$
28.5
$$$$
29.1
$$$$
40.4
$$$$
48.7
$$

7.3

(k) Is ketcno concentration. 
Tabue D

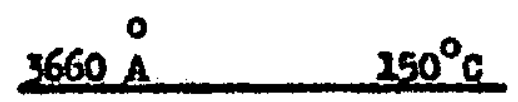

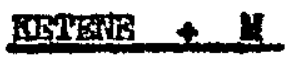

\section{(x) $=1.90$ moles/21tio $\times 10^{3}$}

(n) MOLSS/LETHE $\times 10^{3}$

$2 / p_{C O}$

$$
n=C_{4}{ }^{8} 8
$$

25.03

ii.03

7.20

3.39

53.5

43.3

34.3

20.5

$2.25^{\circ}$

37.7

$u=9 g_{6}$

10.84

16.30

42.2

57.2

4.87

27.3

7.58

34.4

2.24

20.2 
QABIS 8

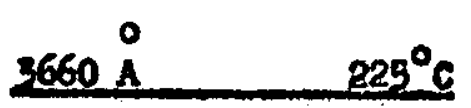

\section{BETPEIB ALONS}
(B) HOLEs/LIZHB $\times 10^{3}$
OPPICAL DEITSIIY
$2 / \phi_{\mathrm{CO}}$
1.06
0.118
4.45
2.20
0.230
5.74
5.75
0.686
20.28
10.79
1. 281
25.22
23.72
18.98

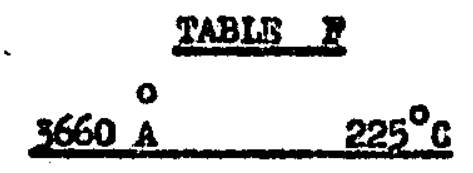
$\operatorname{CABRB}+C_{4}{ }^{2}$
(K) $=1.61\left[10200 / 21\right.$ tre $x 10^{3}$
$C_{4}^{8}$ YOLES/LIIRB $=10^{3}$
$2 / \phi_{\mathrm{CO}}$
6.84
20.34
20.25
21.11
3.32
7.75
2.77
6.58
9.81
10.91 
PABIB G

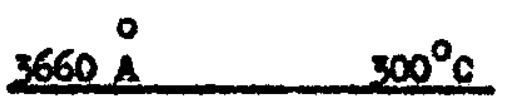

FOFETR AIONOB

(K) $10 \mathrm{LES} / \mathrm{LIFBB}=20^{3}$

OPTICAL DERSTIY

$2 / p_{\mathrm{CO}}$

0.99

0.208

2.87

2.03

0.304

2.87

4.45

0.709

4026

7.33

9.26

9.12

8.96

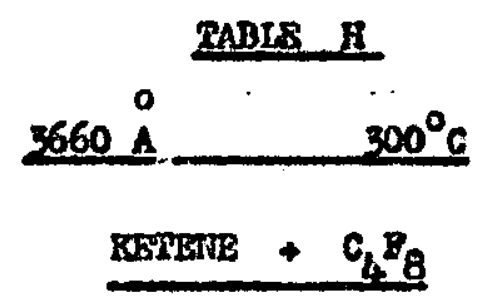

(I) $=2.40$ molen/21tro $\times 30^{3}$

$C_{4}{ }^{8}$ UOLES/LITRE $\times 10^{3}$

$2 / p_{\mathrm{CO}}$

6.29

3.82

3.02

3.75.

8. 38

4.56

2.36

3.26 


\section{TABLP I \\ $3230 \mathrm{~A} \quad 37^{\circ} \mathrm{C}$}

\section{RELTRE ALONE}

\begin{tabular}{|c|c|c|}
\hline (x) rOLES/LTPR $\times 10^{3}$ & OPRTCAL DEATSITY & $2 / \phi_{C O}$ \\
\hline 2.56 & 0.580 & 3.01 \\
\hline 6.24 & 3.288 & 0.99 \\
\hline 0.85 & 0.171 & 2.03 \\
\hline 20.61 & & 0.97 \\
\hline 22.48 & & 1.20 \\
\hline 15.52 & & 0.98 \\
\hline 19.66 & & 2.07 \\
\hline 24.16 & & 1.14 \\
\hline 0.83 & 0.182 & 1.00 \\
\hline 23.70 & & 1.22 \\
\hline 37.84 & & 1.37 \\
\hline 42.33 & & 2.46 \\
\hline 28.25 & & 1.27 \\
\hline 32.62 & & 1.23 \\
\hline
\end{tabular}

(B) 18 ketene concentrotion 


\section{MABLB I}

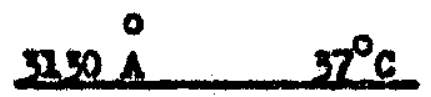

CESTBRB +4

\section{(II) $=2.59$ moled 2itre $\times 10^{3}$}

(a) MOLBS/LTRRE $\times 20^{3}$

$2 / \phi_{C O}$

$$
x=C_{4}{ }^{2}
$$

22.52

2.53

24. 22

1. 32

3.36

1.06

16.92

2.38

7.4

2.12

20.56

1.20

1.32

40.21

80.26

61.76

98.11

0.97

1.77

2.64

2.92

3.00

$u=88_{6}$

20.02

2.40

14.23

1.27

20.76

1.25

3.67

2.07

2.73

2.00

7.7

2.12 


\section{TABLB 8 \\ $3230 \AA \quad 200^{\circ} \mathrm{C}$}

\section{IETHER ALOAR}
(R) $40138 / \mathrm{LITRB} \times 10^{3}$
OPTICAL DERSTTY
$2 / p_{C O}$
2.28
0.553
0.98
20.83
0.243
0.98
0.60
1.603
0.97
6.7
2.603
0.99
19.90
2.08
26.38
1.07
13.48

(K) is keteno concentration. 


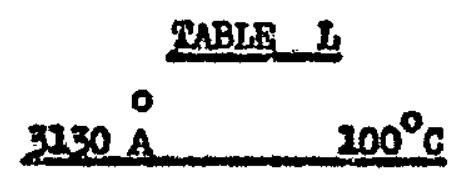

\section{ABTWIITE -4}

\section{(B) $=2.15 \mathrm{moleg} / \mathrm{Ltzre} \times 10^{3}$}

(ii) noLes/hrtes $\times 20^{3}$

:

$$
H=C_{4} E_{8}
$$

32.22

1,50

61.60

2,06

48.90

i.64

81.20

2.43

25.64.

i. 15

$x=s P_{6}$

23.35

2.27

20.28

i.13

4050

3.00

6.45

i. 04

2.88

2.00

2.24

0.98

1.08

0.97

0.77

0.99

2.54

0.97 
Bxperimental values of $k_{g}$, the decomposition rate constant wero colculated from the alopes of the plots of twioe the reolprocel of the carbon monoxdo grantixn yiold egainst keteno conoentration. at $3660 \mathrm{~A}$ and voriour tempersturos. Those alopes aro gqual to the ratio of the rato oonstant for desctivation to tho rate constant for decompostition.

The desotivetion rate oonstents were oalculated from colliaton theory, assuming a colliston damoter for kotono of

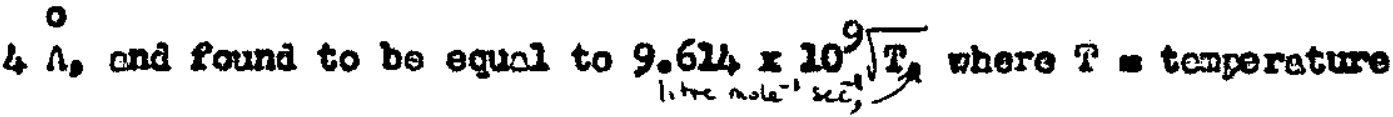
In degrees absoluto. Henco $k_{g}$, the rato conotants for decomposition were coloulated.

The enerey correaponding to these sate constents wos caloulated as Polloms:-

Tho rotational and vibrational eneres of the excited kotene molocules is equal to tho alfferenco botween tho energy of the exciting vevelongth(h') and the seromero enores $\left(B_{00}\right)$, plus tho rotational $\left(B_{p}\right)$ and the ofbrotionol $\left(B_{V}\right)$ enerby of the Ground otatic. 2trub,

$$
\mathrm{B}=\mathrm{Al}-\mathrm{B}_{00}+\mathrm{B}_{\mathbf{p}}+\mathrm{B}_{\mathbf{V}}
$$

Therefore

$$
B-B_{00}=n \gamma+B_{r}+B_{v}
$$

Tho quantities on tho might hand sldo can bo caloulated. Energy of exoiting $4_{\text {ght }}=\frac{n \times h \times 0}{\lambda \times 4.184 \times 107}$ colo., whero $n=A v 0 g a b r o s$ number.

$$
\begin{aligned}
b & =\text { Plenks constent. } \\
& =\text { Volooity of } 11 \text { ght } \\
\lambda & =\text { Mavelongth of the } 21 \text { cht in ans. } \\
2 \text { calorie } & =4.284 \text { joules. }
\end{aligned}
$$


B. tho rotgtional energy of the ground state $=\frac{3}{2} \mathrm{Rx}$.

B. Voluos were obtatned atreotly from the tables of Taylar end Glasstone. 23

Thotr valuos $\frac{B-E_{0}}{T}$ vere oquitialent to $\left(B_{-}-E_{g}\right)_{Y_{i}}$ whoro $\left(B_{v}-B_{0}\right)_{i} i_{i}$ the contribution to $B_{v}$ of the $I_{\text {th }}$ vibrational

Prequency. Vibrational froquencles for keteno woro obtuined frow Bradly Hoore and Plmentel. ${ }^{24}$ Thercfore for sach

temperature the nine contelbutions fron the fundemental vibration froguenoles were saded together and then multiplied by $T$ to gtvo the vibeational enoreg $B$.

$$
\text { Aadition of ht, } B_{2} \text { and } B_{v} \text { gavo values of } \mathrm{I}+\mathrm{B}_{00}
$$

at all the tenperatures used. Those valuos, if th tho experimental values for 206 $_{20} k_{9}$ are shomn in Tablo $\mu_{\text {, togethar }}$ wh somo ata from other workers.

Tho valueb for the thooretion rate of aecomposition and energy were obtainea as followb. Tho theories of rassed 22 and slater 21 for unimolecular reaction lead to an equation of the following form.

$$
k_{9}=P\left(\frac{\left.B-B_{0}\right)^{-m-1}}{B}\right.
$$

Values for $\log _{10} k_{9}$ wero csloulated, using $\mathrm{s}=12$ and $Y=4 \times 10^{20}$, for values of a from 2.275 to $5.0 . B_{00}$ ras

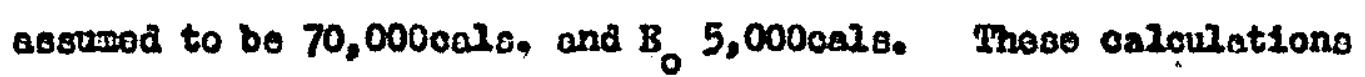
are ahown in Teble $\mathrm{N}$. 


\section{PABLO}

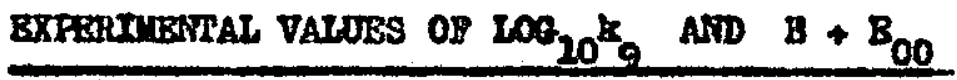

\begin{tabular}{|c|c|c|c|}
\hline $2^{0} \mathrm{C}$ & $\log _{20} x_{9}$ & $B+B_{00} \cos \theta$ & Roforenoo \\
\hline 23 & 6.8255 & 79,392 & 23 \\
\hline 26 & 6.8592 & 79.425 & 6 \\
\hline 37 & 6.9824 & 79.508 & This work \\
\hline 7 & 7.3284 & 79.778 & 6 \\
\hline 207 & 7.5473 & 80,098 & 6 \\
\hline 150 & 7.8222 & 80,485 & This work \\
\hline 254 & 7.9572 & 80,526 & 6 \\
\hline 225 & 8.2788 & 82,249 & This rork \\
\hline 300 & 8.3766 & 82,082 & This work \\
\hline 23 & 8.9489 & 86,882 & 23 \\
\hline 23 & 9.4024 & 92,622 & 23 \\
\hline
\end{tabular}




\section{PABLB A.}

\section{THEORETICAL VALURS OF IOG $_{20} \mathrm{k}_{9}$}

$\therefore 12, \quad \nu=4 \times 10^{10} \mathrm{sec}^{-1}, \quad \Sigma_{00}=70,000001 \mathrm{~s}$,

$$
B_{0}=5,000 \text { 0alo. }
$$

$n=\frac{E}{B_{0}}$

$8+8_{00}$ oals.

$\log _{20} x_{9}$

1.275

78,750

6.5542

2.0

80,000

7.2911

2.5

82.500

8.2623

3.0

85,000

8.6662

4.0

90,000

9.2282

5.0

95,000

9.5362 
As outlined in the experimentel seotion the ahromatogxeph was oalibrated by injeoting knom bomples of carton monoxdde and otrolono, and monguring the aroas of the resultant peaks. Arod/wolo for each gas res rorked out and then the relative cenolitivity of the Instrument to these cases was calculated. The results are shorn in Table 0.

\section{TABRE O.}

(The rosurts are reduced to constivity values of 100 , on tho ingtrument in all osese).

\begin{tabular}{|c|c|c|c|}
\hline Rum & Co(area/molo) & $\mathrm{C}_{2} \mathrm{~B}_{4}$ (areadrole) & $\frac{C_{2} H_{4} \text { arod/mole }}{\text { Co ared/molo }}$ \\
\hline$i$ & 2.38 & 4.18 & 2.76 \\
\hline 2 & 2.32 & 2.66 & 2.02 \\
\hline 3 & 1.897 & 3.20 & 1.69 \\
\hline 4 & 3.66 & 7.28 & 2.96 \\
\hline 9 & 1.56 & 3.02 & 1.94 \\
\hline 6 & 1.95 & 3.81 & 2.954 \\
\hline 7 & 2.304 & 4.034 & 1.75 \\
\hline
\end{tabular}

Hoan relative sensitivity $=2.868$

The $\mathrm{CO} / \mathrm{C}_{2} \mathrm{H}_{4}$ ratios measured vere all multiplied by this faotor to glvo tzue valuod.

CO/C $\mathrm{C}_{4}$ ratios wore neasured at $3230 \AA$ and $2700 \AA$ at $57^{\circ} \mathrm{C}$. These ratios, together with the Golopropang/ketone ratios at wioh they were messured, are show in Tebles $P$, and $Q$. 


\section{TABLB $P_{\text {. }}$}

$3130 \AA \quad 32^{\circ} \mathrm{C}$

\begin{tabular}{|c|c|}
\hline Qyelopropano/ksoteno & Carbon nonoulde/etryleno \\
\hline 13.1 & 6.2 \\
\hline 16.2 & 6.0 \\
\hline 29.5 & 7.3 \\
\hline 19.9 & 7.8 \\
\hline 25.2 & 8.1 \\
\hline 42.2 & 7.7 \\
\hline 31.8 & 8.0 \\
\hline 78.4 & 8.45 \\
\hline 7.85 & 5.0 \\
\hline
\end{tabular}

Throe rung of keteno alone vere done and the $\mathrm{CO} / \mathrm{C}_{2} \mathrm{I}_{4}$ ratlo messured at this wavelength and temperature:

\begin{tabular}{|c|c|c|}
\hline Xoteno prossure(cin.) & \multicolumn{2}{|c|}{ Carbon monoxdide/othylone } \\
\hline 3.0 & 2.2 & ‘ \\
\hline 3.0 & 2.3 & $\imath$ \\
\hline 3.08 & 2.2 & $\cdot$ \\
\hline \multicolumn{3}{|c|}{ TABLB 9} \\
\hline 27004 & $37^{\circ} \mathrm{C}$ & \\
\hline Golopropane/keteno & \multicolumn{2}{|c|}{ Carbon monoxdadothleno } \\
\hline 20.9 & \multicolumn{2}{|l|}{7.5} \\
\hline 28.0 & \multicolumn{2}{|l|}{7.3} \\
\hline 23.6 & \multicolumn{2}{|l|}{7.2} \\
\hline 9.9 & \multicolumn{2}{|l|}{4.4} \\
\hline
\end{tabular}

Ketene was photolysed alono ot $2700 \AA$ and $37^{\circ} \mathrm{C}$. The carbon monoxide/ethylene retio wes found to be 2.3 . 
Results of two runs in wheh kotene was photolysed wth excess of propylone et $3130 \AA$, ana $2700 \AA$, and at $37^{\circ} \mathrm{C}$, aro not cabulated. No otrolene was coteoted in theso rune. 


\section{Drscosstais}

Part I.

THR GHOROLYSIS OP RETREB

\section{Ratene Abrosption.}

Tho optical denstiles observed at alferent wavelengths and temperatures axe 11 ated in Tebles $A, C, B, G, I$ and $R$, and axe plotted against ketene concentration in P1gure 1D. It oll bo geen that Boer's Lat Io obayed at both ravelengths and 21 tenperatures, Indicating that the Ileht trenemted by the Aliters used, was rossonably monochromatlo, Fron the alopes of the $21 n e s$ in Figure 1D, the extinotion coefflatents at $37^{\circ} \mathrm{C}$ vero oaloulated. Those can bo compared wth valuss calculated fron the absorption speotrun of ketene (Bigure 1B.), and with the velues of Fortor and Taylor. 13

MRLSR.

$\mathrm{F}^{\mathrm{O}} \mathrm{C}$

-

A

3150

3660

22

3130

3660

23

3230

3660
Bxtinotion Coefpicient (uttre molo-1 $\mathrm{cm}^{-1}$ )
Raference.

Plgure ID

10.70

$$
2.90
$$

11.70

Fl gure 18

$$
4.20
$$

9.00

Porter end reyjor 13 


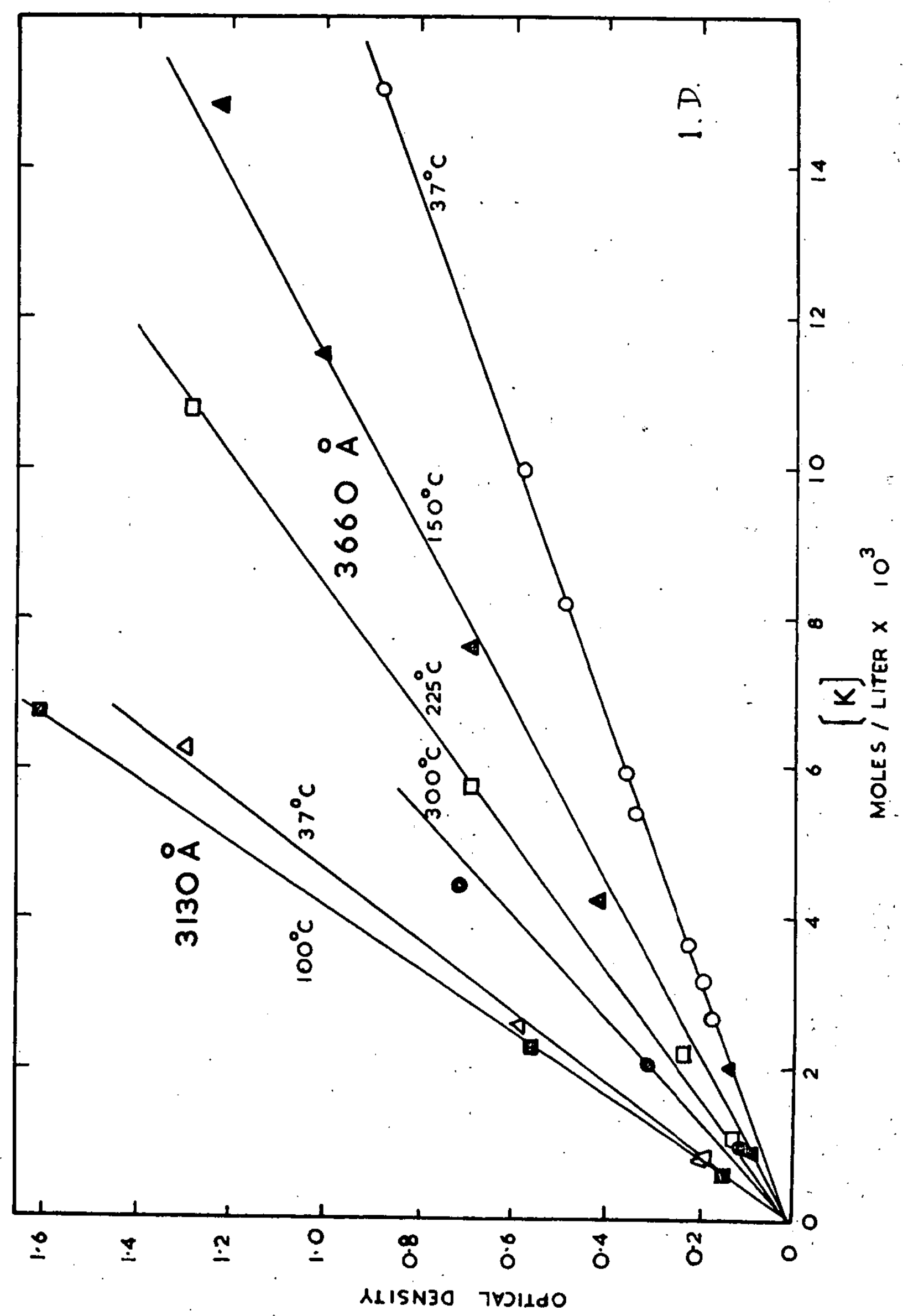


The extinotion coorficients oalculated from tho Beer's Wew date aro in reasonable agreentent with those obtalned from the absorption apectrute of kotene. Samo error is caused in the zatter by the uncertelnty of the position of the base 11ne, when the pootrum was recorded. This leads to orrors in the optlcal denatty values obtalned frot the epeotrum. The values for the oxtinction coaficlente froin tho work of forter and Tay $20 x^{23}$ have been correctod in Fablo $\mathrm{B}$. The Dear'. Las plots, In the paper by theso authors, appear to be correot, but the ralues quoted for tho extinction coefploients, in the text, aro too largo by a factor of ten. Interference fliters wero used to isolate the varlous ravelongths. The Bear's Lan ploto aro linoar up to pptloal cenndty values of 0.4 , but then aeviate from the stralght linos, indicating that light of a difforent wavelongth was present. This would acoount for the alightly lower value whoh theso authore find for the extinotion coerplesent at $3230^{\circ}$. The dechani on of the protolrois.

Tho results obtalned with kotene alone, and keteneInert gas mixtures aro best explained in terms of the reactions and transitions shom in Higure TD (facing page 50 ). Spectroscoplo ovidence and theoretioal calculations place the triplet otato and tho first oxcited singlet stato of kotono 61 and $74 \mathrm{koal}$ molo $0^{-1}$ rogpeotively, above the ground state. 25 $3660 \stackrel{\circ}{\circ}$

On the above besis, ebsorption at $3660^{\circ} \mathrm{A}$ wi2l reant In the formation of exoltod singlet state wolecules with approxdmately $4 \mathrm{koal}$. mole $\mathrm{e}^{-1}$ of vibsotional eneres. 

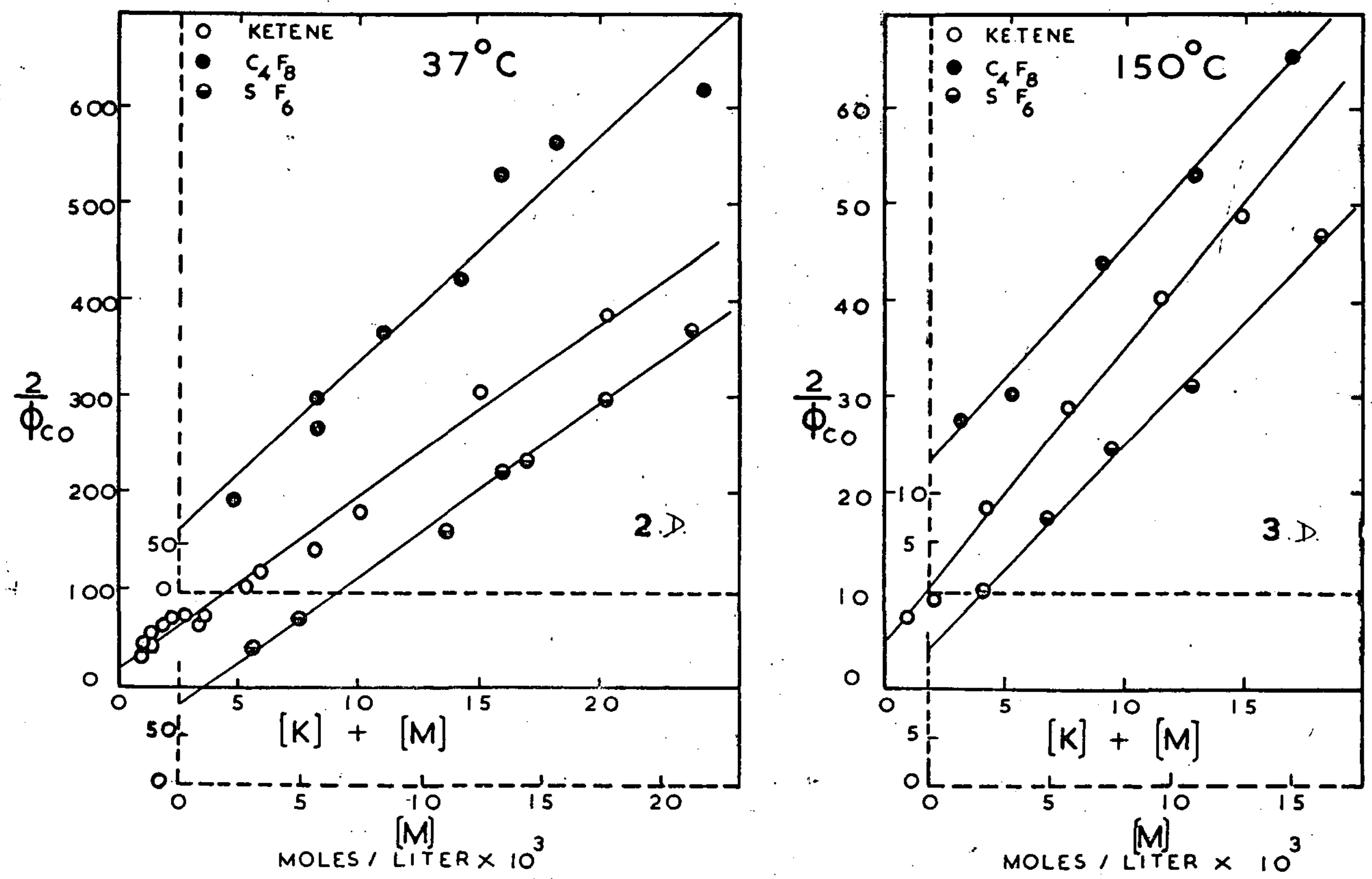
These way then undergo the throe alternative processes seen In Figure 70 as [2], [3] and [4]. [2] 10 deconpooltion into elnglet wethyzene $\left({ }^{\top} \mathrm{CH}_{2}\right)$ and carbon nonoxide. There is evidence thet cone eloblet nothylenes are forned at $3660^{\circ}$, although eatiantes of the percentage of the total wethylenee we1ch are olnglet at this wavelength vary, 26,41. [3] 1 . interayster crossing to the triplet state. Other workeres 26 now agres that this is an intrasolecular process and is not collieion induced. The triplet state formed by [3] lo asoumed to live long enough to reach thoral equilibriue. Then it can undergo deconposition into triplet aethyleno $\left({ }^{3} \mathrm{CH}_{2}\right)$ and carbon anoxide, [5], or intersyeten croseing to the ground state [6]. The fate of oinglet and triplet nethylene is ascuned to bo reaction with keteno to form ethylene and carbon monoxide. Conpeting with [2] and [3] 1o colisulonal deactivation [4]. Since the average vibrational onergy tranoferred per colileson to polyatonic deactivators in other oyotens has been round 27 to be approximatels $10 \mathrm{koal}$ nole, ${ }^{-1}$ it lo probable that alngle collision with elther ketene, or one of the two gasee added, so oufficient to doactivate the excited afnelet otato molecule to its lowest vibrational leval. Flgures $2 D$ and $3 D$ confira the rindinge of previous workere 6,13 . that there is no tendency for the carbon monoxide quantur yield to rench a 1Lmiting value at high concentratione. Buch a phenonena, which is obeerved in come other ayetens 52 , would be expected if elther decompesition or intereyaten croselng were occurring frow the lowest vibrational level of the excited sluglet etate. 
Intoroyetom croosing from this lovel of the ofnglet stete hao boor included in provious cochanieno pootulatod for totone photolysio 10,42 but the evidence doos not oupport the occurrenco of such a step. It appoars that fros thio Iovel, internal convoreton io conolderably faster than either decoaposition or intereyoter crosolng, and takea place to tho excluation of both. A Past intornal convorolon proceso [?] would also oxplain uhy no fluoresconce from lotono has over beon obsorvod, dooplte sevoral attompte to PInd it. The abovo processes nay be written

$$
\begin{aligned}
& \begin{array}{l}
\mathrm{B}+\mathrm{hH}(3660 \mathrm{~A}) \longrightarrow{ }_{\mathrm{B}} \longrightarrow \mathrm{T}_{\mathrm{B}} \\
\mathrm{T}_{\mathrm{B}} \longrightarrow \mathrm{T}_{\mathrm{CH}}+\mathrm{CO}
\end{array}
\end{aligned}
$$

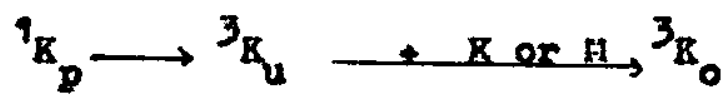

$$
\begin{aligned}
& 1_{B_{p}}+\mathrm{K} \longrightarrow \mathrm{I}_{\mathrm{B}}+\mathrm{K} \\
& \mathrm{B}_{\mathrm{B}}+\mathrm{H} \longrightarrow \mathrm{I}_{\mathrm{B}}+\mathrm{H} \\
& \mathrm{B}_{\mathrm{k}} \longrightarrow{ }^{3} \mathrm{Cn}_{2}+\mathrm{co} \\
& \mathrm{B}_{\mathrm{B}} \longrightarrow \mathrm{R} \\
& I_{\mathrm{B}_{0}} \longrightarrow \mathrm{x} \\
& { }^{\top} \mathrm{CE}_{2}+\mathrm{E} \longrightarrow \mathrm{C}_{2} \mathrm{~B}_{4}+\mathrm{CO} \\
& { }^{3} \mathrm{CH}_{2}+\mathrm{B} \longrightarrow \mathrm{C}_{2} \mathrm{H}_{4}+\mathrm{co}
\end{aligned}
$$

where $\mathrm{B}$ represento a ground otato noloculo of ketono, f a nolocule

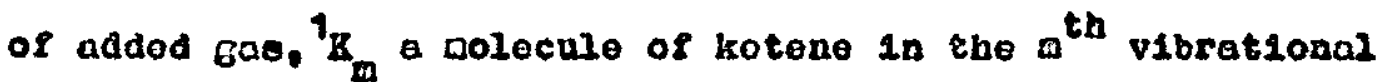
levol of the oxolted olnglot otate, and ${ }^{3} \mathrm{~B}_{n}$ a aolecule of kotene In the $n^{\text {th }}$ pibrotional lovel of tho triplot otato. 


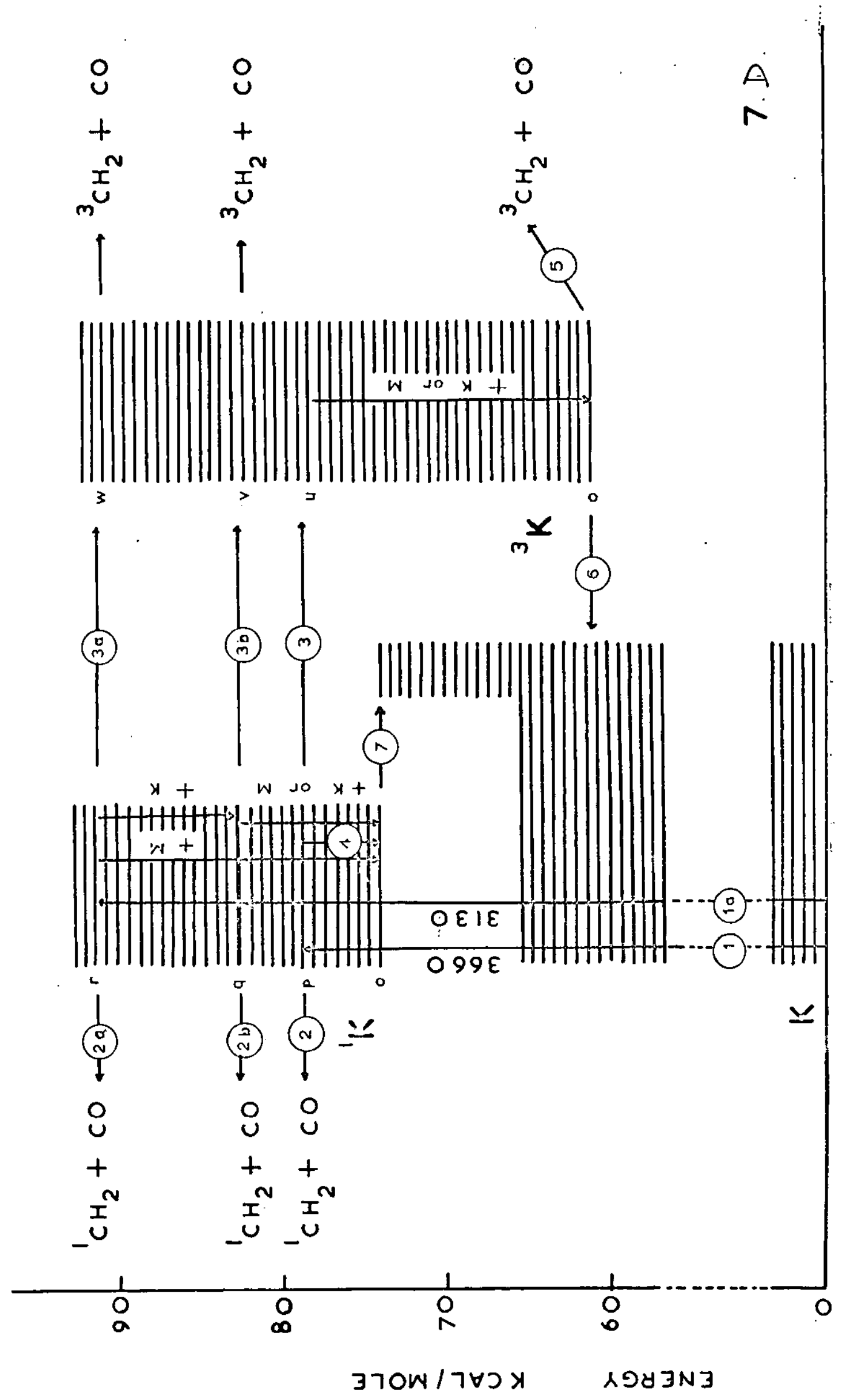


Applicotion of tho unual oteady stoto ansumption 20RAs tos-

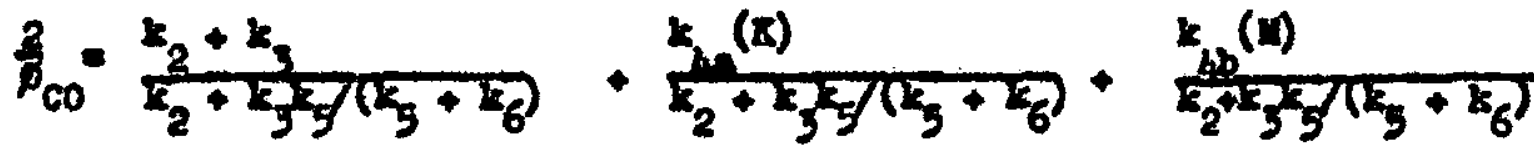

and

$\alpha=$

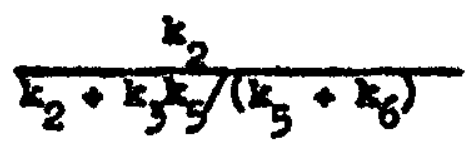

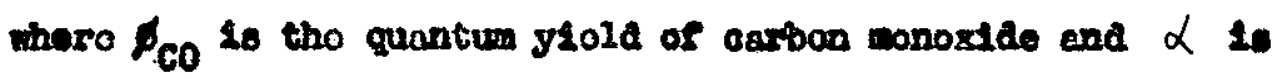
the ercotion of asthylenos somed whloh are ainglat.

Figures 20, 3D and 4D how how, at all temparatures,

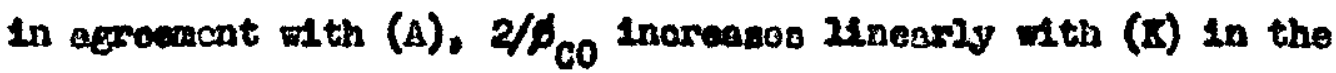
absonce of added gas, ond 2lnearly whth (v), at constant coneentration of retene. Furthermore, at the two lowor teaperatures tho elopos for the threo alrforent ganes (soo Table S. below) are all of almilar magnitude, a resurt whioh would bo expeoced if [ 4a] and [4b] occur on orory colliaton.

\section{ZABLB B.}

\section{$3660 \AA$}

IFETSR ALOATE

\begin{tabular}{|c|c|}
\hline $\mathrm{P}^{\circ} \mathrm{C}$ & s2ope (colos $\left.e^{-1} 11+\mathrm{re}\right)$ \\
\hline 37 & 17.680 .0 \\
\hline 250 & $3,050.0$ \\
\hline 228 & $2,232,0$ \\
\hline 300 & 966.0 \\
\hline
\end{tabular}

Intercegt $x_{2}+k_{3}\left(4.00^{-1}\right)$
$20.05 \quad 1.91 \times 10^{8}$
$4.63 \quad 3.00 \times 10^{8}$
$3.35 \quad 6.36 \times 10^{8}$
$0.84 \quad 2.01 \times 10^{8}$

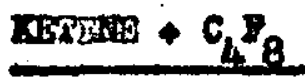

รొC

Slope(moles $-131+50)$

37

$23,350.0$

250

$2,820.0$

225

530.0

300

158.0 
2ABIB \& (Continue6)

\begin{tabular}{|c|c|c|}
\hline $2^{\circ} \mathrm{C}$ & & 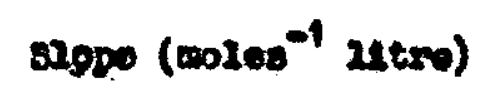 \\
\hline 37 & & 17.950 .0 \\
\hline 250 & & $2,580,0$ \\
\hline
\end{tabular}

Appreciablo thernal polymerisation of keteno occura at the hiptrer teaperotures. Fhe exportnental results at $225^{\circ} \mathrm{C}$ and $300^{\circ} \mathrm{C}$ (itguro 4D) aro thereforo 2000 rellable than thowe at $37^{\circ} \mathrm{C}$ and $150^{\circ} \mathrm{C}$. Neverthelose tho alfferences between the sloper

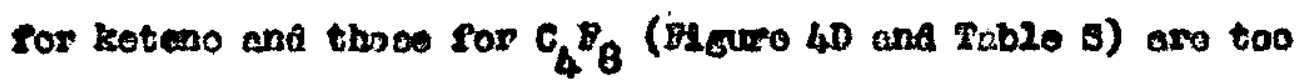
20rge to be kcoountod for by experinental arsor. In 81gure 201

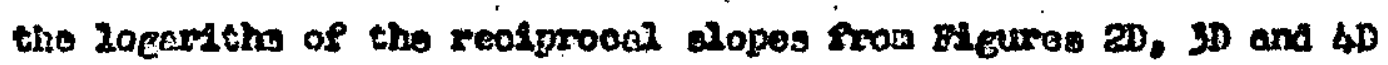
aro plotted againot the realprocal of the aboolute temperature.

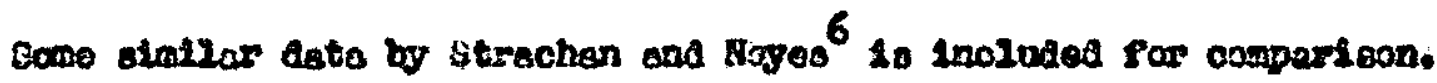

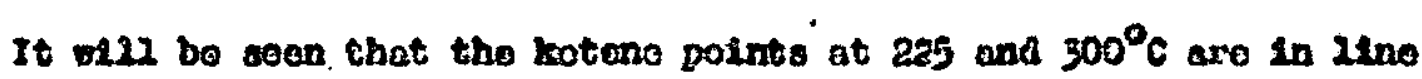

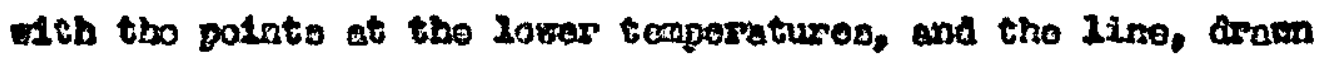
though those polnte, bas a stalles alope to shat flteing the date of strechan ond hoyes. Dut the $\mathrm{C}_{4} \mathrm{P}_{8}$ polnts at 229 ad $300^{\circ} \mathrm{C}$ aro quite alearly out of 11ne. $\triangle B$ tho tenserature is ralsod, $\mathrm{C}_{4} \mathrm{P}_{8}$ preare to renove

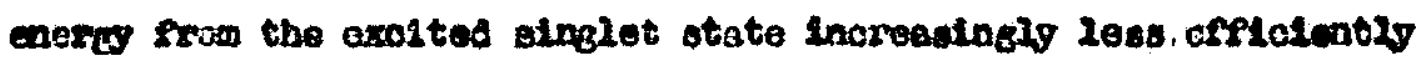
then kotene. Cno posalble explanstion is thet sapo of. the colliolions of the higher teaperatures result in enerby tranufor to, ratines than from, tho exoltod alaglot otate. 


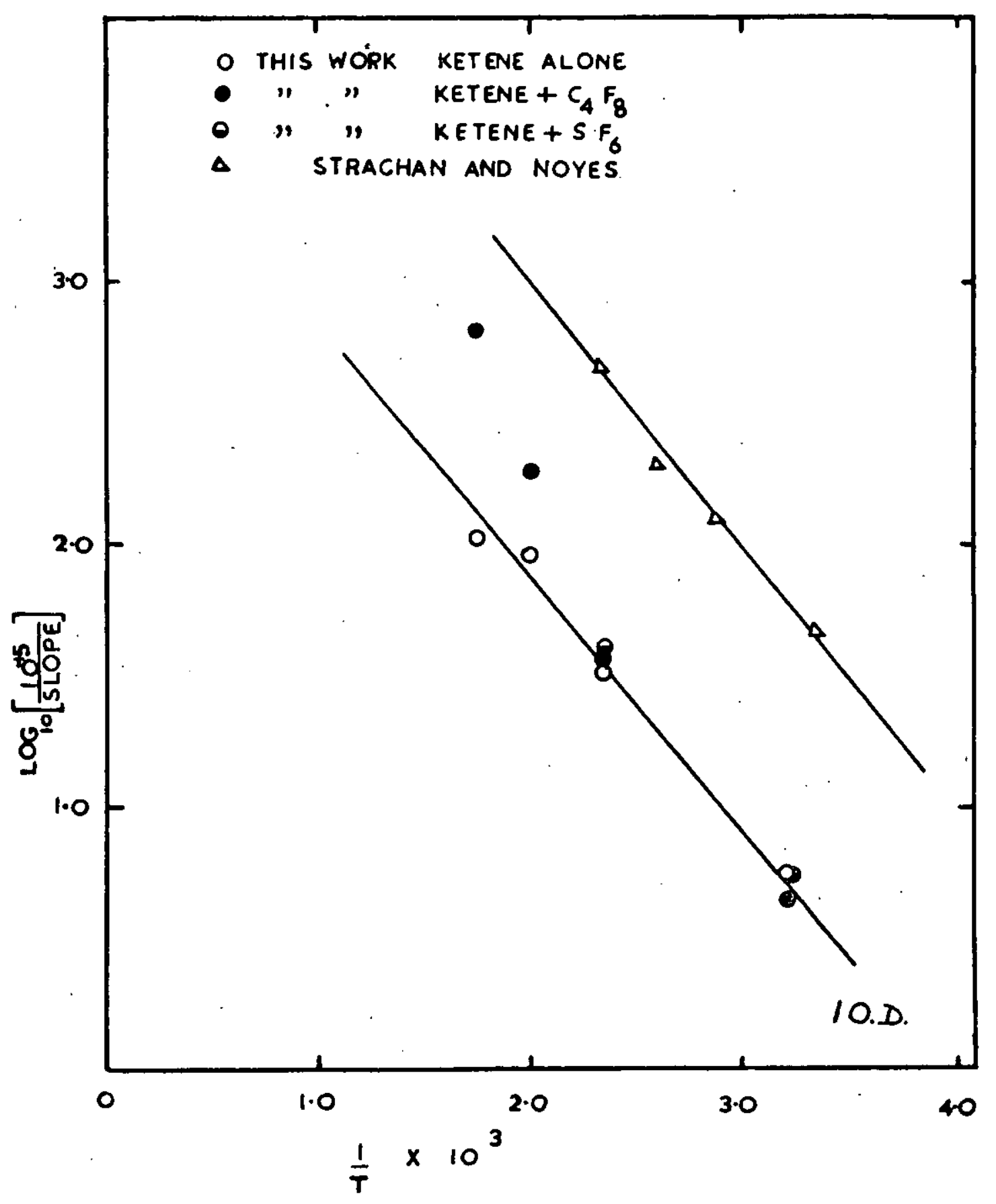


If, beceuse of tho grester number of its pibrational modes, tho average eneray transferzed from $C_{4}{ }^{8}$ were lerger than from koteno, a fraction of the oxested ainglet stete molecules courd, on colliston, be coquiring suefialent enorbs from $C_{4} g_{8}$. to decomposo, but insueficient to. do so fron keteno. In this way $\mathrm{C}_{4}{ }_{8}$ woula becomo 1060 effeotsvo at lowering the caxbon monoxido quantum yleld than koteno, as observed.

Hithout a knowledgo of $\alpha$, it is not possiblo to calculate or aselgn velues for all the Individuel sate constants. But sono oaloulotions and essienmonts can bo mado and conolualons aram. Assuming a collision dranoter for keteno of $4 \mathrm{~A}$ and thet [4a] oocurs on every collision, the value of $\mathrm{k}_{48}$ is

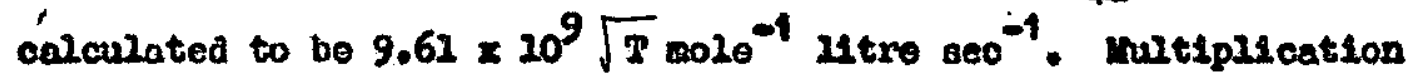
of $4_{40}$ by the intercepte alviaed by the slopes of the $2 / F_{C O}{ }^{7}$. (R) plots ofreo $k_{2}+k_{3}$, whose velues aro 4 sted in gablo $s$. $k_{2}+k_{3}$ sppears to increaso ollightly ith tempernture. (Tho valuo et $300^{\circ} \mathrm{C}$ is unrelsable as tho intercept vould bo expected to bo greated then unfty). The absence of fluorescence, and the lack of evidence for decomposition or intorsyoten croseing ocourring from the lowest vibrational 20 vol of the excited ainglot state suggests that $k_{7}$ hse a value groator than $20^{9} 800^{-1}$. Tho doorease

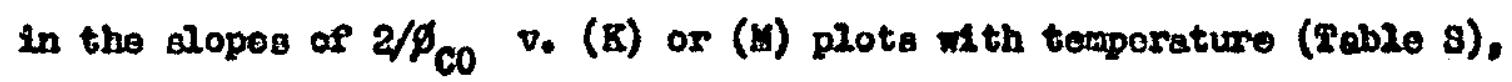
insteotes that (5) hos a moll activation eneres. If $\alpha$ is sero at this wavolength, this aotivation enorey yill be around $3500 \mathrm{0uz} / \mathrm{moz} \theta^{28}$. If $\alpha$ is not sero, the valuo w1Il be greater. $3130 \AA$

Absorption at 3130 A lead to the formation of expited alnelet state molecules atth approxlmately 17 realo of vibretional enoxbs. 
Pablo I, and Afure 5D, chow that the carbon monoxdde quantum gleld is congtent ond, wthin crperimontal crror, oqual to 2.0 at Iow prescures, and only begins to deorease ot pressures Ereater than 200.m. This is in reasonable afrocuent with the findinge of

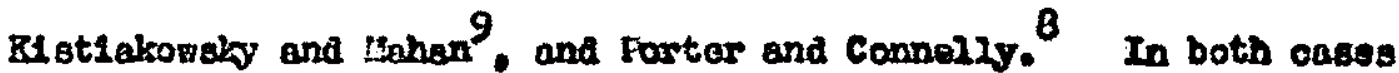
Pilter solutions wore used to ieolate the $3230 \mathrm{~A}$ reglon, os in this work. Taylor and porter ${ }^{23}$, ualng interfaranoe sultera, found quantur yields constiorably lower than thoso raported of ther bere or by the authors mentioned above. This lack of agrecment makes it probable that Teylor and Portor asd not leolato $3230 \mathrm{~A}$ efficient2y, and that the interference piltere vere tranenitting acno 2leht of longer morlength.

$\Delta$ carbon monoxide guantun yield having the value 2.0 at 10w prossures, indiostes that every colecule absorbing a quantum under these conaltions ultiogtely decomposes. There is evidence, from other work, 26,29. that not all the wothyzenos formod on decomposition are oinclot. This con bo explained if interaystem crooolng [3e], sollowed by deccaposition frim a high vibrational Ievel of the triplet state, is competing with alrect aeoomposition, [2a] (B1gure 7 ).

The most 21kely oxplanation of tho departure frot Lnearity of the $2 / 9_{\text {CO }} \nabla$. (B) plot, shown in PIgure 5D, is that coll1etonal doootivation 18 mintista6\%, ${ }^{10}$. and that only part of tho 17 kcoal of vibretional enores of tho exolted singlot stato woleculo is lost os a reault of its firot collialon with hoteno. After this flrst colliaion, the exoltca nolocule still retathe ourfialent vibrational enorey to decomposo $[20]$ or undergo Interasoten oroesing to the triplot state [30], srow which it then Coooraposes. 

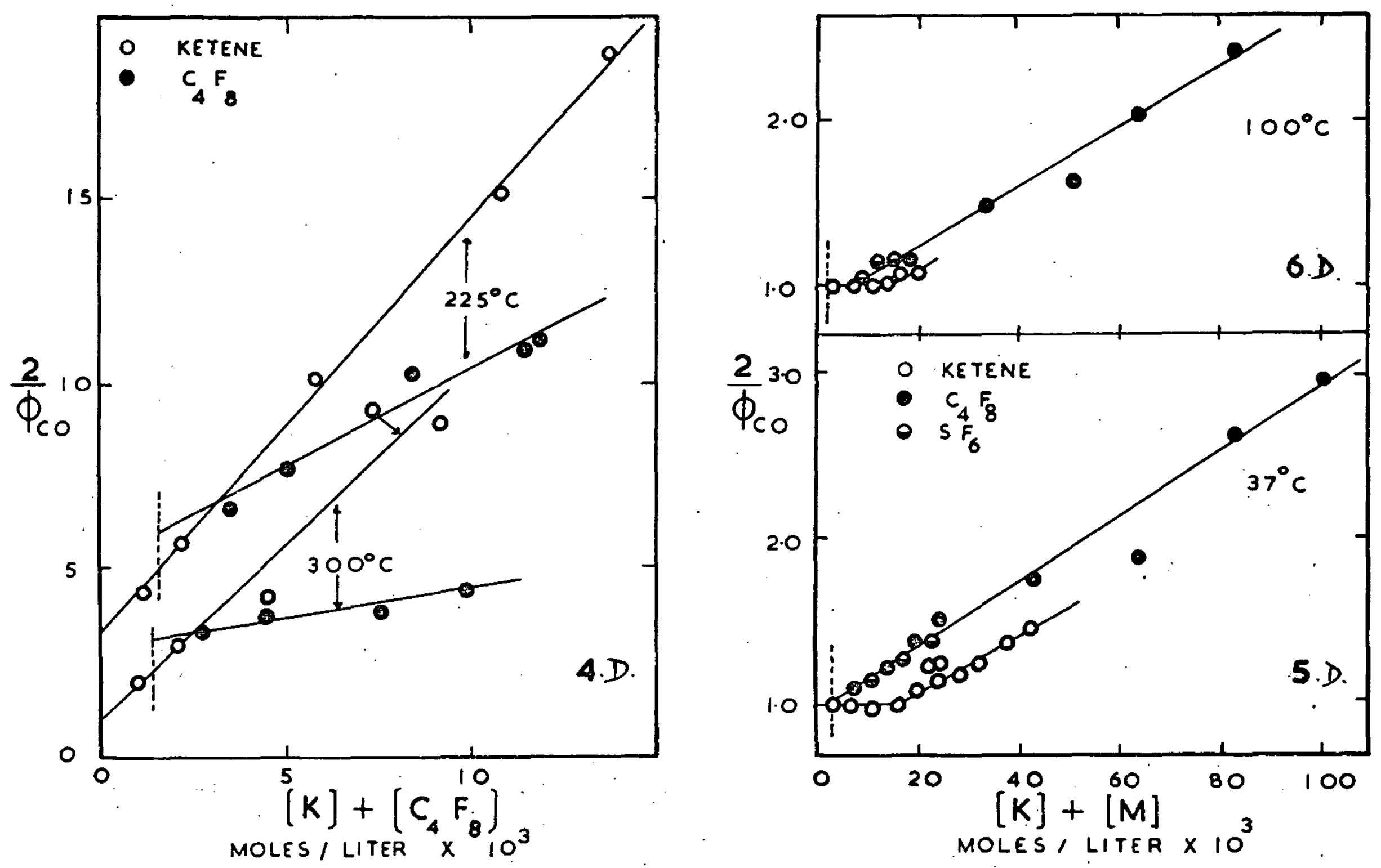
Only after additional collisions does tho excited singlet otate moleculo 2080 all 1ts excess vibrationnl eneres. The data are not diffelolentis accurate to ellow ary of the mothods for deterinining the number of cosotivation otages ${ }^{20}$. to be appliod. But a tromstege proesss secms the most Iikely and, as all be shown later, will edequately account for the data,

BLgure 5D ahowe that when Inaxt 80808 crolo-h 48 and $89_{6}$ are used at the ravalength and $37^{\circ} \mathrm{C}$, with oud canotant enounts of kotene, the plots of $2 / \phi_{C O} \nabla_{0}$, (u) aro 21near aith unt Intercept, and tho pripary quantur yiald $\phi_{c 0} / 2$ 10 reduoed beloz unt by the onellest, guantities of inort cas used. Both $\mathrm{C}_{4} \mathrm{~F}_{8}$ and $S_{6}$ have more vibritional modes than beteno and might bo expeoted to absorb greater emounts of plbrationed energy than ketero on colliation wh tho excelted alnglet state molecule. Thus while the latter roquires at least two collielons for deactivation by ketene, It pould otill bo deactivatod in a atingio collision by $C_{4}{ }_{8}$ and $S P_{6}$. Suoh alnglo otage deactivation by $C_{4}{ }^{7}$ and $8 P_{6}$ would acoount for shall additions of of ther gos lowering the primary quantue jield, and for $2 / \phi_{60}$ lnoresaling 2inearly ofth pressure of inort ges. Such an explanation moans: that the major part of the $17 \mathrm{kcal}$ of vibrational enerey possessed by the excited woleculd is lost on 1ts first colliaton with elther of the Inert gases: Ints is not unressonadie in the 11ght of. the obeenvations of othor workers on tho amounts of energy transforred per collision during the deaotivation of vibrationally oxnitod maleculos? 
As the tesperature is ralsed, core ibrational modes of $C_{4}{ }_{6}$ and $8 B_{6}$ becono cotivo and the capacity of the two gaves for absorbing vibrational onereg on collsaton is corresponatagly raduced. There is a likelinond of singlo stage doectivation fiving way to a tro-atege process at higher temperstures. Evianose of this ohanes is to be found in the data $200^{\circ} \mathrm{C}$ (Teble is and Plguro 6D). In contrast to $37^{\circ} \mathrm{C}$, at least $200 \mathrm{~mm}$ of $\mathrm{C}_{4}{ }^{8}$ or $35_{6}$ have to be adaed before tho carbon anoxide quentun yleld is roluoed aignsflosntiy, and the asference between the deactration behaviour of tho two geses and thit of ketene 18 1088 conited than at $37^{\circ} \mathrm{C}$. 2his would be explained if deootivation by $\mathrm{C}_{4}{ }_{8}$ and $\mathrm{SF}_{6}$ becomer alintar to that bo ketene, nanely two-gtage, at $200^{\circ} \mathrm{C}$. The aldontly greater deactivation ereicicnoy of $\mathrm{C}_{4}{ }_{8}$ and $88_{6}$ is undorstendable if on the first colliaton, the excitod singlot stato molccule still $20 s e s$ more energy to elther of tho inert gases than to keteno. It w12 then be reduced to a Iower vibrational level aftor an inart gas colliston than after a colliolon with kotene. Decomposition and interwsten aroseing from this lower level will be alower than from tho higher 1evol, reachod aftor an encounter alth koteno, and thus tho tro inort cocos wil ronin alchtly more afflolent anotivatore than koteno. 0 The processes ocourping at the 20wer tengerotiure at 3130 \& may be written?

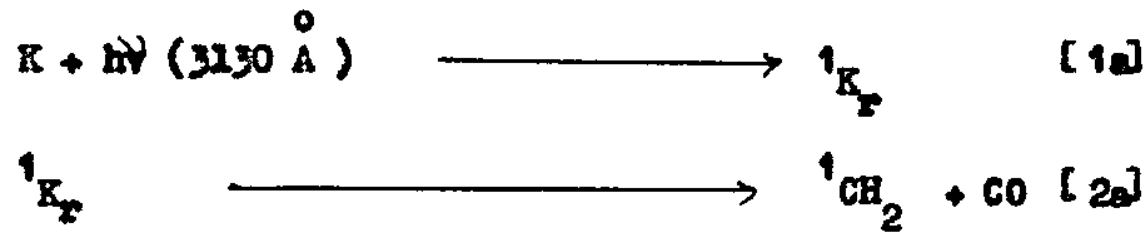


$-56-$.

Tho processes occurring at the lower temperatiure at $3230 \AA$ A may, be writtent- (Continued).

$$
\begin{aligned}
& { }^{4} \mathrm{R}_{\mathrm{F}} \longrightarrow \mathrm{L}_{\mathrm{V}} \longrightarrow{ }^{3} \mathrm{CH}_{2}+\mathrm{CO} \\
& 1_{\mathrm{B}}+\mathrm{B} \quad \longrightarrow \quad \mathrm{I}_{\mathrm{g}}+\mathrm{X} \\
& B_{q}+k \quad \longrightarrow \quad B_{0} \cdot R \\
& \mathrm{r}_{\mathrm{r}}+\mathrm{I} \longrightarrow \mathrm{q}_{\mathrm{g}}+\mathrm{u}
\end{aligned}
$$

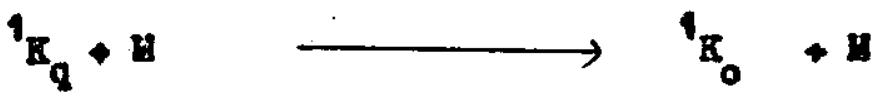

$$
\begin{aligned}
& { }^{1} \mathrm{R}_{\mathrm{q}} \longrightarrow{ }^{1} \mathrm{CH}_{2}+\mathrm{CO} \quad[2 \mathrm{Ob}] \\
& { }^{1} \mathrm{~B}_{\mathrm{q}} \longrightarrow{ }^{3} \mathrm{~K}_{\mathrm{q}} \longrightarrow{ }^{3} \mathrm{Cn}_{2}+60 \quad[36]
\end{aligned}
$$

Application of the stesdy atate asungtion loads to,

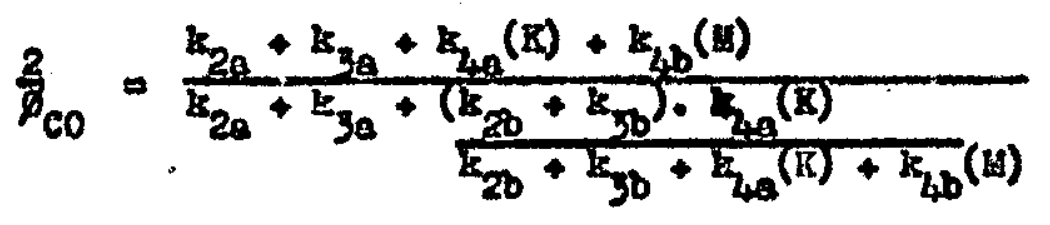

and when $M=0$,

$$
\alpha=\frac{k_{2 a}+\frac{k_{23}+k_{40}(x)}{k_{20}+k_{30}+k_{40}(x)}}{k_{2 B}+k_{3 a}+\frac{\left(k_{20}+k_{20}\right) k_{4 B}(k)}{k_{2 b}+k_{3 b}+k_{4 B}(k)}}
$$

$$
\text { Srom (c). }
$$

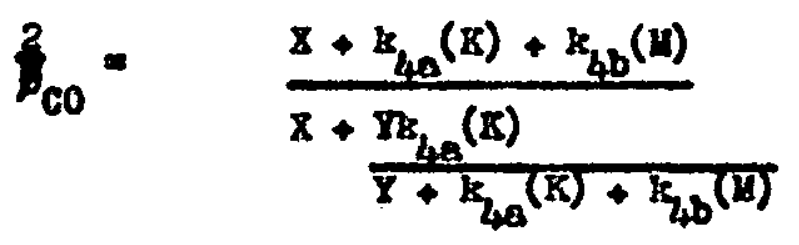

there $\mathrm{I}=k_{2 a}+k_{30}$

$$
\text { ons } x=k_{20}+k_{30}
$$




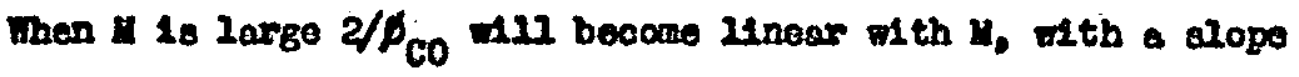
oqual to $k \mathrm{~g} / \mathrm{x}$. Figure 5D show that this is observed when 4 is $C_{4} B_{8}$, the Ilmiting alope having the value 29.6 (moled/21tro) Ilence $k_{4 b}=29.6 \times(\text { moleg/ } / 140)^{-1}{ }_{800}^{-1}$

At $3660 \AA k_{4,0} / k_{40}=27,680 / 23,330$

and thareforo

$$
\begin{aligned}
& k_{4 B}=19.6 x=(27,680 / 23,330)(\text { moloi } / 11 \text { tro })^{-1} \mathrm{seo}^{-1} \\
& k_{4 a}=24.9 x(m o l o d / 214 r o)^{-1}{ }_{600}^{-1}
\end{aligned}
$$

Decompostion from the $q^{\text {th }}$ Level of the exolted ainelot ancton the $w^{\text {th }}$ level of the triplot otate, should be elower

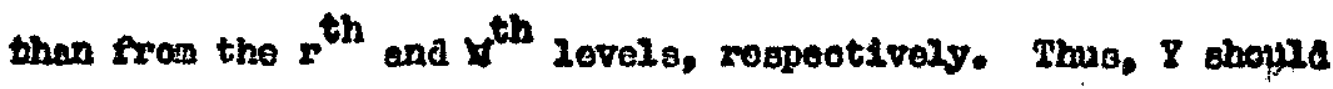
bo 20 s than $X$. IP wo asaume $Y=X / 4$, and using $k_{40}=14.9 X$, and $k_{4 b}=29.6 x$, wo eina.

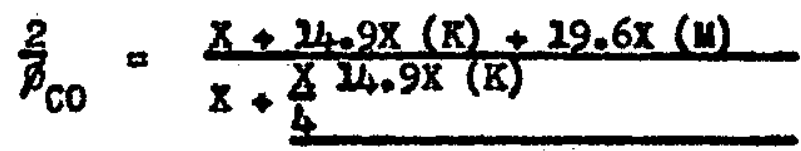

$$
\begin{aligned}
& \frac{x}{4}+4.9 x(x)+29.6 x(H)
\end{aligned}
$$

and

$$
\frac{2}{g_{C O}}=\frac{1+\mu_{4.9}(R)+29.6(B)}{1+\frac{\mu_{4.9}(\mathrm{~K})}{1+59.6(\mathrm{R})+78.4(\mathrm{I})}}
$$

$\operatorname{then}(\mathrm{H})=0$

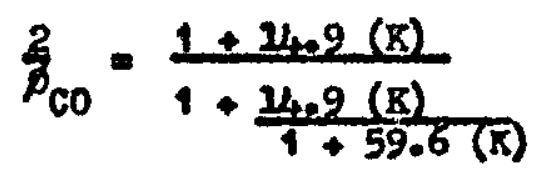

and when $(K)=0.00259$.

$$
\frac{2}{f_{C 0}}=\frac{1.0386+29.6(1)}{1+\frac{0.0386}{1.2544+78.4(1)}}
$$


Bquation (B), and tho values of ( $(\mathrm{X})$ used experdmentaly, were

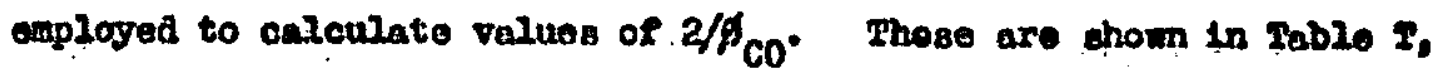
togethor with the experimentel values.

Equation (P), and the values of (U), used at constant (B), were employed to calculate values of $2 / f_{\mathrm{CO}}{ }^{\circ}$ These are shom in Tablo $\mathrm{J}_{0}$ together with the experimental valuos.

\section{TABES}

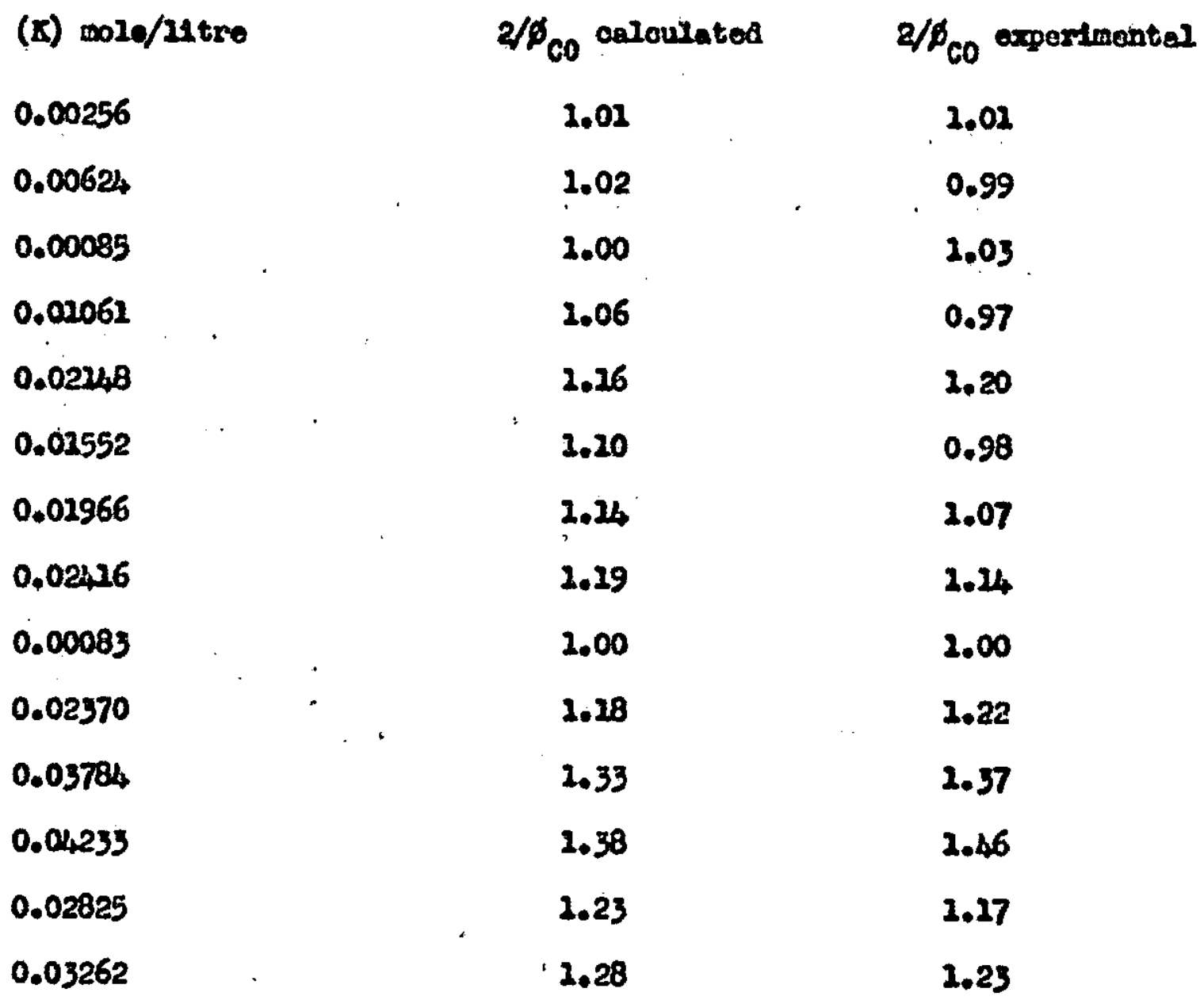




\section{PABLB U.}

(R) $=0.00259 \mathrm{~mole} / 21 \mathrm{tro}$

\begin{tabular}{|c|c|c|c|}
\hline $\begin{array}{l}\text { (U) mole/21tre } \\
u=C_{4} B_{B}\end{array}$ & & $2 / \phi_{60}$ oplculaced. & $2 / \varphi_{c 0}$ experimantal \\
\hline 0.02152 & & 1.44 & 1.53 \\
\hline 0.01422 & & 2.30 & 2.32 \\
\hline 0.00336 & & 3.08 & 1.06 \\
\hline 0.01692 & & 2.35 & 1.38 \\
\hline 0.00714 & & 2.25 & 2.12 \\
\hline 0.02056 & & $2 \cdot 22$ & 1.20 \\
\hline 0.00132 & & 2.03 & 0.97 \\
\hline 0.04022 & & 2.01 & 2.77 \\
\hline 0,08026 & & $2 \cdot 60$ & $2: 64$ \\
\hline 0.06176 & & 2.24 & 2.91 \\
\hline 0.09821 & - & 2.95 & 3.00 \\
\hline$*$ & & . & , \\
\hline$A=S 86$ & & . & , \\
\hline 0.02002 & & 2.40 & 1,40 \\
\hline 0.01423 & & $2: 30$ & 1.27 \\
\hline 0.02076 & & 2.23 & 1,25 \\
\hline 0.00338 & & 2.08 & $2: 18$ \\
\hline 0.00794 & & 2.17 & 2.05 \\
\hline 0,00367 & & 1,08 & 2.07 \\
\hline 0.00173 & & 2.08 & 1.00 \\
\hline 0.00772 & & 1.26 & 1.22 \\
\hline
\end{tabular}

-These points are not plottea in Higure 11D, to avoia confuaton with $C_{4}^{B}$ posints. 
Tho results of those caloulations are plotted in Figure 21D. Tho solla lines are the calculated values of $2 / \phi_{\mathrm{CO}}$ end tho pointo oro the experimentally deterained values. Tho good agresmont between the calculated and oxperisental values shows thist tho propoced mechanten, with 1 ts two stage deaotivation by koteno, and single etage denctivation by inert gases, adequately ccoounts for the expersinental date at $37^{\circ} \mathrm{C}$. Tho data at $100^{\circ} \mathrm{C}$ bove not been treated in the camo wos as those at $37^{\circ} \mathrm{C}$ beosuse the altuation at the Migher teaperature is more complscatiod. Although $C_{4} P_{8}+{ }^{9 P_{6}}$ ot2LI deactivate the oxcited singlat state molecules more effeotively than koteno at $100^{\circ} \mathrm{C}$, decomposition or

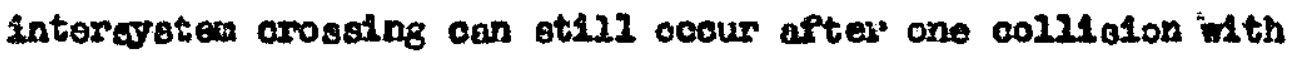
those Gases. The Vortation of $\mathrm{s}_{\mathrm{g}}$ with Energy:

If the meohanten proposed above is correot, the alopes

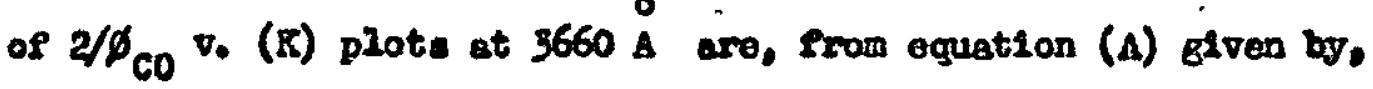

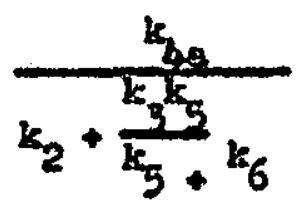

Tho linting elopes of aimfiar plote at $3130 \mathrm{~A}_{\text {, at }}$ ald conoentrations of koteno, are sron equation (C) equal to

$$
\frac{k_{2 a}}{k_{2 a}+k_{3 a}+k_{2 b}+k_{3 b}}
$$

Therefore tho olopes at the two wavelengtho are forven by different expressions of rate constante. Previous torkers $8,20,13$, and moro reoently Bowers 51 havo assumed that the alopes at the alfierant wavelengths are alrootly comparable. 


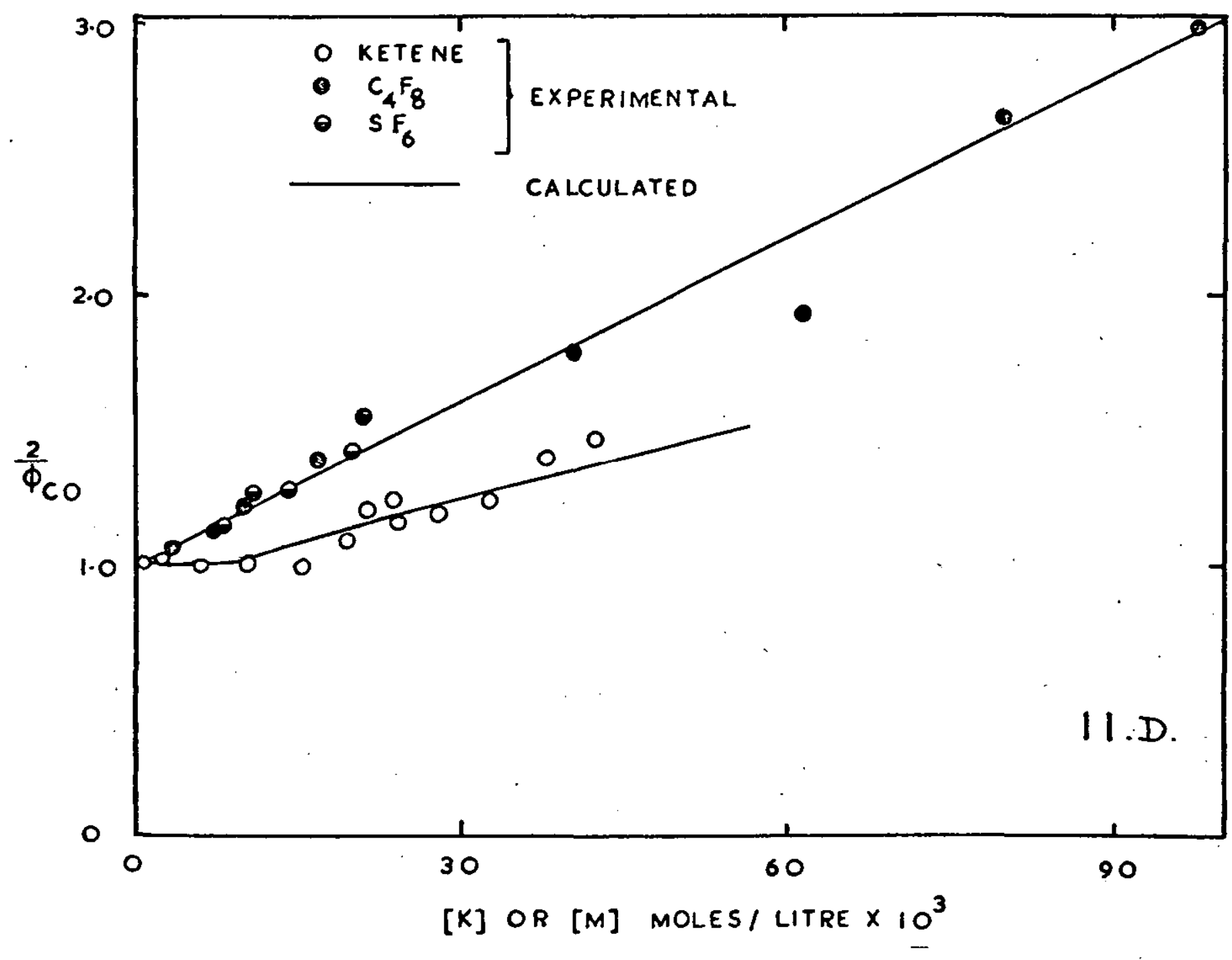


Thw have essuried tho ofmpler mechanles,

$$
\begin{array}{ll}
\mathrm{CH}_{2} \mathrm{CO}+\mathrm{HO} \longrightarrow \mathrm{CH}_{2} \mathrm{CO} \cdot \\
\mathrm{CH}_{2} \mathrm{CO}+\mathrm{CH}_{2}+\mathrm{CO} \\
\mathrm{CH}_{2} \mathrm{CO}+\mathrm{OH}_{2} \mathrm{CO} \longrightarrow \mathrm{CHI}_{2} \mathrm{CO} \\
\mathrm{CH}_{2} \mathrm{CO}+\mathrm{CH}_{2} \mathrm{CO}
\end{array}
$$

whioh Loacis to

$$
\frac{2}{f_{c o}} \cdot 1+\frac{k}{k_{9}} \cdot \frac{k_{10}}{k_{9}} \quad\left(\mathrm{ma}_{2} \mathrm{co}\right) \text {. }
$$

The 8lopes are then ell equal to k $1 f^{\prime} k_{g}$ and tholr varlation with ravelergth and ceapersturo has been abouned to zafleot the vesiction of $k_{9}$ with onergy. That this assumption is invalld, and tho acchenis used too afaple, is shown when tho apparent veluos of $k_{g}$ are compared with one arothor and atth theory. The collision devotivation rate constant, in this case k $10^{\circ}$ has been caloulatod proviously, essuming a collistan blenotor for ketane of

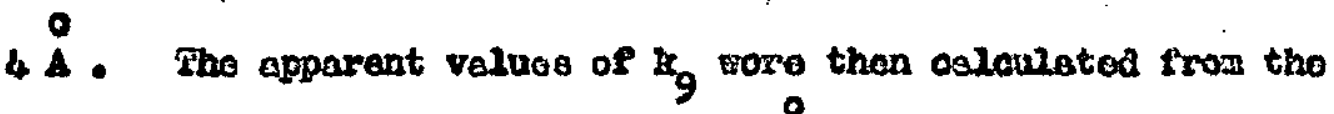
aloper obtained in thito work at $3660 \mathrm{~A}$. Thoee aro $110 \mathrm{cted}$ together with value of other woxisoro, in Seblo 1 (poge 4I). Plots of $\log _{20} \mathrm{~kg}_{9}$ (the theorotical deconposition rate constant) eqeinst $E+Z_{00}$ ware Aram for values of $\mathrm{B}_{00}$ from 70.6 to $68.6 \mathrm{k0a2} 0.010^{-1}$

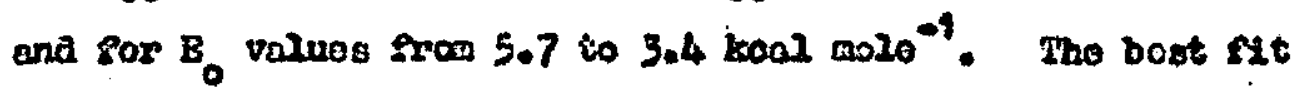
botween the exportirental and theorotioel valuos was cohieved when

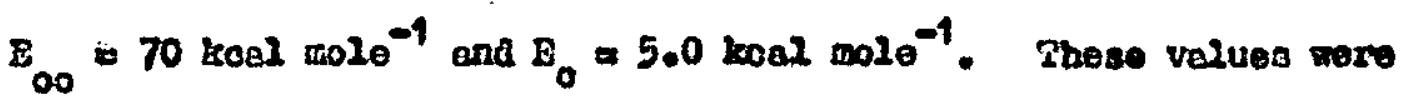

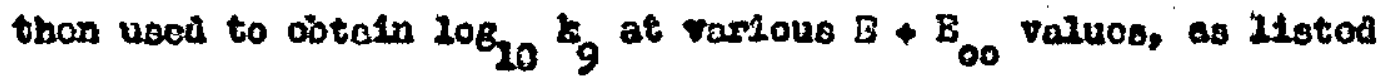
in Fabio 8 (pago 42), and plotted os the dotted ine in PIgure BD. Also on this plot aro experinontal voluos, shown as tho solsa 2 ine. 


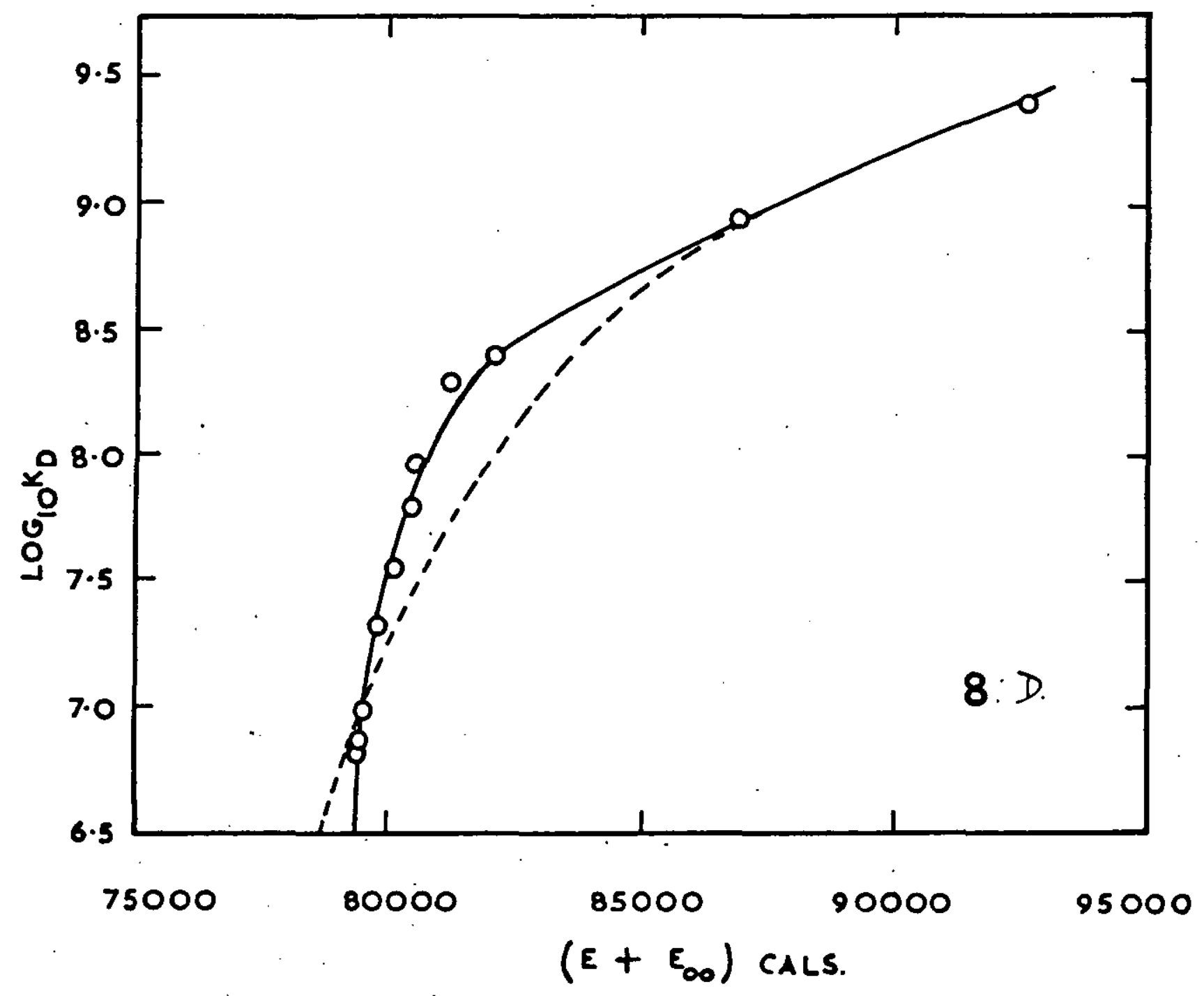


The experimental Ine deviates from the anooth thooretical ourvo and exhibits a suaden change of slope between $E+B_{00}$ values of 79.5 and $87 \mathrm{kcal}$ mole-1. Such a near discontinuity annot be explained on the basts of seactiono(8) - (21) and provideo evidence In favour of the aro complex meohanisw, in which tho alopes at the alfferent wavelengths are not alreotly comparable.

If the more complex mochenim proposed in this rork Is correot, it should otill bo possible to invostigete the veriation of the rate constents for decomposition of the excited alnglot stato $\left(k_{2}, k_{2 a}\right.$ and $\left.k_{20}\right)$ with oneres, if $\alpha$, the proportion of total wethylenes formed which are singlot, were knom. Tho slopes at $3660 \mathrm{~A}$, and the lintting alopes at high concentrations of kstenc at $3230 \AA$, alviaed by $\alpha$ voula glve $\frac{k_{k} a}{k_{2}}$ and $\frac{k_{4 A}}{k_{2 B}+k_{2 b}}$ respeotively. Tho determination of $\alpha$ is tho subjeot of Part II. 
PARP II

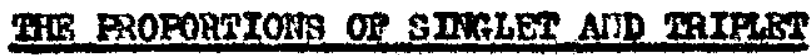

HYHate

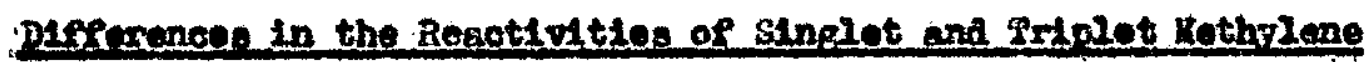

Before congldering the doternination of the proportions of alnelet and triplet mothyleno, it is necesaary to rovtew the ordienoe for alfferences in the resotivities of the states of notivilone.

\section{Adastion to Carbon - Carbon Double Bonds.}

Bkell and Woodwosth 32 end Dooring end Laklame 33 obrerved

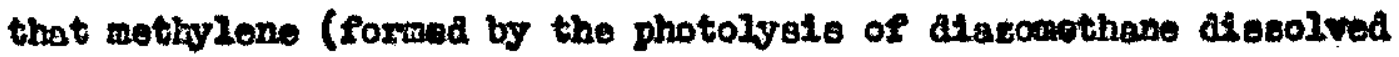
In hydrocarbon) added ols stereoppecificalizy to the double bond of ois of trans buteno - 2. The stereospecifloity coupled wth the raplasty of the reaction pointed to the methylene so formod boing in the singlet stats. 37,32 . It is now generally ecopted that the addition of ainglet wethylane to the carbon - carbon coublo bond is stereospeoiflo, and ocours vis the formation of an oxcited ayolopropene which isomerles to othor produote, if not stoblilized by collistons. 47

Ballowing Roriberg's dotection of the speotrue of triplot athylene, when alasowothene was Plash photolysed in the prosence of an excess of inert gas, 27 prey photolysed alazomethene In the presence of both argon and ols butene-2.57 The totul pressures ranged from 210 to $320 \mathrm{om}$, and tho argon to ads buteno-2 ratio variod from $7.6 / 1$ to $2600 / 1$. Ho Pound that as the ratio Increased the stereospoelficlty of the adatton ruotion was lost. This was taken es oridence that triplet metholone adds to carbon carbon aoublo bonde non-otereospeolfloally. 
Aldition of a gall anount of oxygen greatly dearessed the produots Povoured by diution ath argon." sinoe oxgen, being t triplet opeoles 1tsolf, would be oxpeoted to ronot readily with triplet methylene or its addition products, this seened to conpind the presence of triplot mothyiene in this aystem.

Benson and Dellore 38 pointed out thet allution of the reastion mixcure with argon, whilo malntalning a constant totel pressure, 10eds to decressed desotivation effictency. Hence the 20ss of stereospecifiol by may result from geonetrio Isomerisation of the intial oxol tod aducts rather than from a different mechanisu of rosotion of triplet mothylene.

Howerer, Breg's contention that triplot mothlene resotions were bolng observed is supported by the rork of Drmean end Gotenovic. 39 Those euthors avolded the disodvantages of working with eas mixtures of such high allation, to produre triplet methylone, by ualng the mercury - photosenaitized decomposition of ketene. In this aysten Wh ols buteno - 2 as added olefin, thes found that the product zat1os becane canetant at prossures grestor than $500 \mathrm{~mm}$ and that tho valnes of those ratios wero very simller to those obsorved by Froy 37 of his higheat inert ges to olefin ratio.

Thus doapite Benson and Deltare's doubts, the ovidence does point to tho forilation of triplet nothylono in these aystens and to 2 to adding to oarbon - aerbon double bonds non-stereospeolfically. Suoh non-atercospocifio adaltion is expleined if it takes place vie the fonnation of a alradical in which rotation about the formor doublo bond occure before absequent cyolisetion or 4 sonorisation. 


\section{Insoution Into Crrbon - Evarogen Bonds.}

There io consletrable oridence that ainglet methyleno Inserts Into corbon - harogen bonds. The rork of Dosring and Pringbach ${ }^{34}$ nelped to establish this. They used the reaction of nethyleno ath isobutene, Iabclled with carban - 4 in tho 1 - poattion. A number of products were fared in this reaction but the ano of Interest was 2 wothyl butene - 1. Ires' 35 had shom that, in this wsiem, the yola of 2 mothyl butene - I was Independent of tho total pressure of the aysten. Thi Indicated that the reans of formation of this produot was by insartion into one of the $C$ - I bonds of tho mothy2 exoups. If it were the zoeult of tho

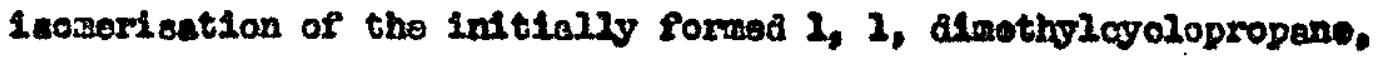
then 1ts yleld would be preseure dependent. Bowever a radicel Fenction schene could be responstble for the foration of 2 mothe butene - 1, but this wourd lead to sorabiline in the $\mathrm{C}-24$ labellod isobuteno ayotem. If the resction to eive 2 mothyl butene - 1 were alrect insertion, then all the $c-14$ should appear in tho 1 - ppastion of the proanot. Dooring and Pringbach found no soramilng in the IIquta phase, ena in the geo phase, only 8,3 of the $C$ - I4 appeared In tho 3 - position. Ihds ahowed that direot insertion wos the major reaction pathray.

Durthermoro, adaitional evidence inatcates that it is aniy singlet wotholeno wioh resotg in this way and that triplot mathylene does not insert into oarbon - hodrogen bondi. In Brey'. axperiment witb tho motholene - 0le buteno - 2 ygrea, 57 the g101a of the insertion produot 2 - mothyl butono - 2 deolsnod frou $12.9 \%$ to 48 as the inort zas to of butene - 2 ratio was inoreased. 


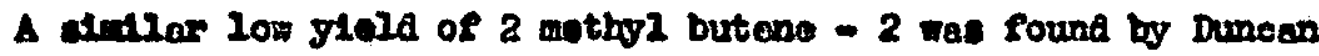
and cretanovio 39 wen telplet nothylene, from the arercury photosenditied decompostion of kotone, was reacted with cls buteno - 2. The medavel gleld of thle product oen be eccounted for by the 1somerication of tho alrealoal foxwed when triplet wothylene ads to the olesin.

Durther ovidence that triplet nethylene coos not undergo tho insertion meotion is to bo found in the comparison of the bigh prossure glelds of the products forsed when alnglet notholeno (fros the photozysis of alaconothano) and telplet athylene (from the meroury photosenstised deconpostion of koteno) rosot with 1 cobuteno (Table v).

\begin{tabular}{|c|c|c|}
\hline Uethozeno & - Isobuta & \\
\hline & ${ }^{1} \mathrm{CR}_{2} 35$ & ${ }^{3} \mathrm{CH}_{2} 39$ \\
\hline pane & 573 & 9280 \\
\hline & . $\quad 348$ & 6.58 \\
\hline & $8 \%$ & $2.3 \%$ \\
\hline & $\alpha$ & $0.5 \%$ \\
\hline
\end{tabular}

The Ineronsed gleld of the adaltion produot $\lambda, \lambda$, almothylayolopropane, and deoreaned ylelds of the insention produoto, 2 methyl buteno -2 and 2 mothyl butone -2 , in tho triplet wothyleno ayoted as conparod

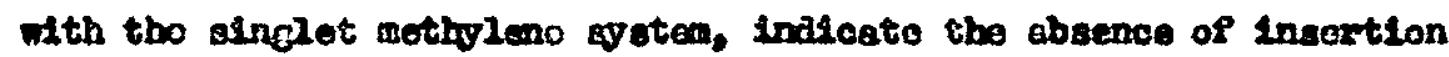
Into carbon-wydrogen bonds by triplet methyleno. 
The onall ylelds of the three mothyl butenes in the triplot methylene qotem 18 again accomted for by tho isomeribation of the dradioal Pormed wen tho anthyzeno triplet ads to tho olefin.

Thus the atferences in the reactivities of singlet and triplet mothol tene may be sold to be falriy well estabilabea. Singlet metwiene adds ateroospeotfloaly to carbon - carton double bonds, wereas triplet methylene addo nonmatereospootelcaliy. Singlot motbylene inserts into carbon - hydrogen bonds but triplet nothelono does not.

\section{Datemination of the Proportions of sinelet and Triplet Mothriono.}

Int22. gutte recently it was genereliy assumed that in the plotolysis of alocomothane and in that of keteno, at normal pressures, only singlet methylene was forrod. But over the pest fow geares orldenco has boen accumlating that oono triplot mothplene is aloo senersted. Bres ${ }^{30}$ has pointed out that the postulation of triplet states in those, and enslogolis aystems, holpo in tho suplification and interprotation of aum exporimontal results. One relovent exanplo is in tho observotions of strachan and noyes ${ }^{6}$ on the offeot of oxygen on the quantum yteld for the formation of ethyzene in the photolysto of kotene. The effeot can be explainod by pooturating tho formation of ${ }^{\circ} \mathrm{CH}_{2} \mathrm{COCH}_{2} \cdot$ with a relotively 20ng Ilfotime. 31 The reaction of this ratioul wh oxggen, and 1ts lorg 21fotime are both consigtent of th it belng formed by the reaction of talplot metholeno with ketone. 30

The deteraination of the proportions of singlet and triplet mothylene formed in tho photolysis of those tro compounds has been the oubjeot of several rocent publications. 
Tho differences in tho reactifities of the two wothylenes with rospect to the carbon - asrbon doubze bond end tho caxbon - byarogen bonde of olefthe have formed the bagls of all the doterminations so far publlahed.

Slmons and Rebinovitch ${ }^{29}$ estinated that there was .29\% triplet wothylene forwed at high preseures in the ajsten kotene c1s butene $-2 \mathrm{a}_{0}$, or ols buteno $-2 \mathrm{~d}_{\mathrm{B}}$ at $3200 \mathrm{~A}$ and $25^{\circ} \mathrm{C}$. The proportion of triplet appeared to be prescure depandent, increasins from a omall or saro value at low presoures to a constant level at high pressures. A afoliar emount of triplet mothyieno and a amilar pressure dependenoe vas found by Rabinovitoh and Dorers 40 . with the ketene - butene -l ayeten at the same wavelength and temperature.

Ho, Unger and Noyes 41 photolysed ketene in the presenco of ols butene - 2 in two wavelength rectans. Prow the produot composition they estinated that in the reglon $2650-2950 \mathrm{~A}_{\text {. }}$ $98 \%$ of the wethylenes forned wore alnglot. In the longer wavelength region, $3460-3820 \mathrm{~A}$ the proportion of alnglet wes wall below 50\% Rabinovitoh, Patkins and Rang 42 photolysed both ketone and alazomethane in the prosence of ofs butane - 2 , (and in one experiment ethyleno), over a pressure rance whtoh went up to several atwospheres. A máximun eppearía to occúr in tho proportion of trplot aetiolens in both aystems at around ono atmoaphore. Tho temporature offect roported in thio work was alstinotis oda. The proportion of triplot wetheleno was found to incresse as the teaperature was ralsod in tho Afescathans systen, but to dicresse as the tenporature ras solsed in the ketene aystom. 
Riatlakonsty and Carr 26 pbotolysed ketens in the presance of trans butene -2 and celculated tho percantaces of triplot motholeno foxwed at 2800, 3130, 3340 and $3660 \mathrm{~A}$. In axperinonts ath added oxsgen, producte whloh were a romut of triplet mothlone roaotions were ellninatia. Dthene and mothano were entirely exsminatod by oxygen. Compaxicon of mun with and whout oxyeen onabled the author to oxioulpto the anount of products formed by triplet mothylene, and, to eatsuate tho grantitios of "txiplet upen products that vere rorsed by isoneriation of the ginglot nothyleno - trans butene - 2 'bot' edauota. Tho variations in methane and ethane production with the wavolength of tho inotient 21 ght wore tho seuse as those of of 1,2, atmetby layolopropane and 3 mothy buteno - 1 . The authore therefore conoluded that wothano and anno were forwed as a revult of triplet metrilene ebstroction rasctions. raking thd into account thoy estimated the proportions of taplet trothylene as $15 \%$ at 2800 and 3130.4 . $30 \%$ at $3340 \mathrm{~A}$ and 40,5 at $3660 \stackrel{\circ}{\mathrm{A}}$.

Haknight, leo and Rowlande 43 vary recently reported 293 os motholene - $t$ in the water CFEC = 0 - othylene, photolysed ot $3230 \mathrm{~A}$.

It can be seen that agrocmont between thi findings of tho alferont suthor:, discused obove, is not gooth In all cases ketcre or alascmethane was photolysed in the presenco of an olefin. The rellablitity af this mothod wao guestloned by Cundall and Davis 44 , wo suggested that the edaed olerin might quanob excitod state triglet, henco altaring the alotribution of mothylen betreen its anglot and triplot states. 
The results obtained by those woxtars rore not roproauciblo and Later mork ghowed that the isonerisation of ols butene -2 , in the keteno - of butene-2-8yoten at $3230 \mathrm{~A}$ and $46^{\circ} \mathrm{C}$, was very alight. 46

Although the quenching of triplet keteno by the olerin Io thus ruled out, there are other reasons for questionthe the rellability of using added olefin to dotornino the relative enounts of singlet and triplet motiviens present. uncentulatios extst in guoh syateas as to how much of a given produot is formed stom ainglet mothylene and how moh from triplot wethplene. The triplot adation product may also bo formed by the leomerisation of the 'bot' Blinglet mothylena - olefin adurt. Tho inglet metrolene Insertion product gay also be formod by tho isonerisation of the triplot motrylene - Olefin alradion. Nurthermore, to svold isomorismtion of 'hot' molecules, high pressures have to bo used whith promote the oonveraton of alnglet asethylono to triplet metrolene 37.48 and thoreby alter the proportions of the tio apeoles present. These unoeztaintios my account for tho lack of agreantent botween the resulte, aisoussod ebove, of the afferent woxkers using this method. Whey make it doalrablo: to.find alternetive methods to olefin adation for detormining the proportions of the two methylenes prosent.

Ono alternative method which has been suggeated by Ristiakorsky and Decrefe 45 is the use of carbon monoxide. Thay found that ixiplot motlyleno reacted nore readily ith carbon monoxide than afa olnclet, and therefore triplet motivlono could be ressoved, and the reactions of sinelot mothyleno stuated. They gave no estimate, however, in their note of the relative proportions of the tro mothylenes forrod in the photolysts of ketene. 
A sooond alteanstive method is to edi cyolopropane. The posalbizities of thts mothod, end the results obtained using It will now be alscussod.

Photolyals of Xoteno - Crolopropano ulxturos

The insertion reactions of methylene occur only with the singlet state. In the photolysio of keteno - ojolopropane mixtures, at high cyolopropano/keteno rat10o, It was expeoted that all the alnglet mothyleno rould ronot ath tho hydrooarbon, whist the triplet moula reaot wh ketene. Priplet wothylene could, however, reaot with tho oyolopropane, abstreoting $B$ bodrogen etam to forw wothrl, and zeading to mothano and otheno as by produots. mevious rork indicated that the contribution from this rooction was silght, and that the onounts of wethane and othine formed vere sinall. 49 , The wain reactions occurring at hiph ayolopropane/zoteno retlos ware thoraporo expooted to boi-

$$
\begin{aligned}
& \mathrm{Ha}_{2} \mathrm{CO}+\mathrm{h \nu} \longrightarrow{ }^{1} \mathrm{CH}_{2} \text { ar }{ }^{3} \mathrm{CH}_{2}+\mathrm{co} \\
& { }^{1} \mathrm{CH}_{2}+\mathrm{C}_{5} \mathrm{H}_{6} \longrightarrow \mathrm{C}_{4} \mathrm{H}_{8} \\
& { }^{3} \mathrm{CH}_{2}+\mathrm{CH}_{2} \mathrm{CO} \longrightarrow \mathrm{C}_{24}+60
\end{aligned}
$$

Where ${ }^{1} \mathrm{CH}_{2}$ and ${ }^{3} \mathrm{CH}_{2}$ aenoto ainglot and triplet wotholeno respoctivals.

$$
\begin{aligned}
& \text { (Total c0)- } \mathrm{Cgh}_{4} \cong 00 \operatorname{sran} \\
& \text { and } \\
& 3_{\mathrm{CH}_{2}}: \quad:=\mathrm{C}_{2} \mathrm{H}_{4} \mathrm{fmom} \\
& \risingdotseq \quad{ }^{1} \mathrm{CH}_{2}+{ }^{3} \mathrm{CH}_{2}
\end{aligned}
$$

Hence 
Hanes (Cont'd)

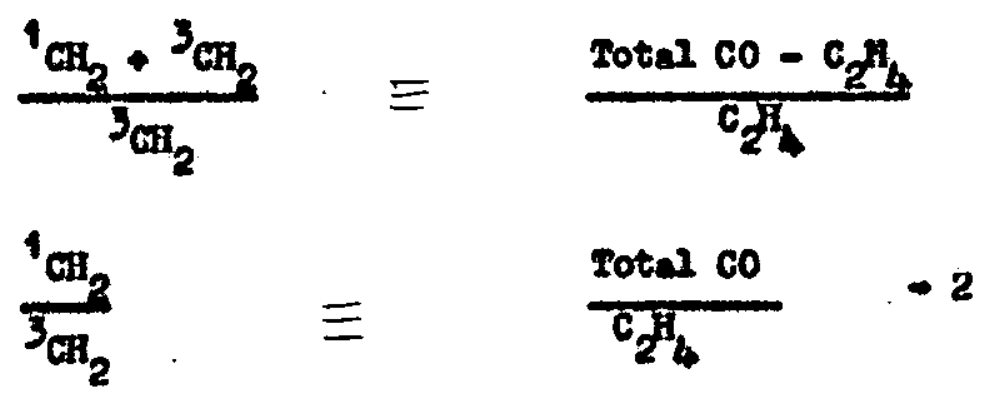

$\Delta 100$

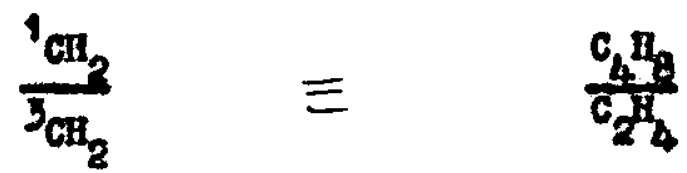

Bxporimentelly, in acroesent wh this mechentem ourbon monoxide, -thylone and $\mathrm{C}_{4}$ hydrocarbons wore the onjy major products formed. Traces of athane and othane wers dotected but thoir ytelds were very sall in comparison with those of the othor products (seo page 22). Mathare and othane are by produots in the photolyals of ketene $-\mathrm{a}$ - butene ${ }^{49}$ and kotene - butene $-2^{26}$ alxtures. Their absonce es elenifioent by produotis in tho cyolopropan - kutene mixtures mast indioate that the sate of todrogen abstraction by triplet methylene from egclopropane is conslderably slower than fron olther $n$ - butene or butene -2 , This is to be expected if the reactifity of ${ }^{3} \mathrm{CH}_{2}$ is einalar to that of $\mathrm{CH}_{3}$, whose relative rates of hydrogen abstraotion, at $37^{\circ} \mathrm{C}$, from arolopropane, $\mathrm{n}$ - butane and butane - 2 are is 28 , 203 respoctively. 50

It was diffioult to obtain colums and condetions which would apparato carbon monoxtde, othylene, excess oyolopropano and tins lasertion producto frow each othor, and from the lapurities In the eyolopropane. The peake of the Insortion produots occurred on tho tall of the oyolopropane peak, os ald somo impurities in the tydrocaxtion. 


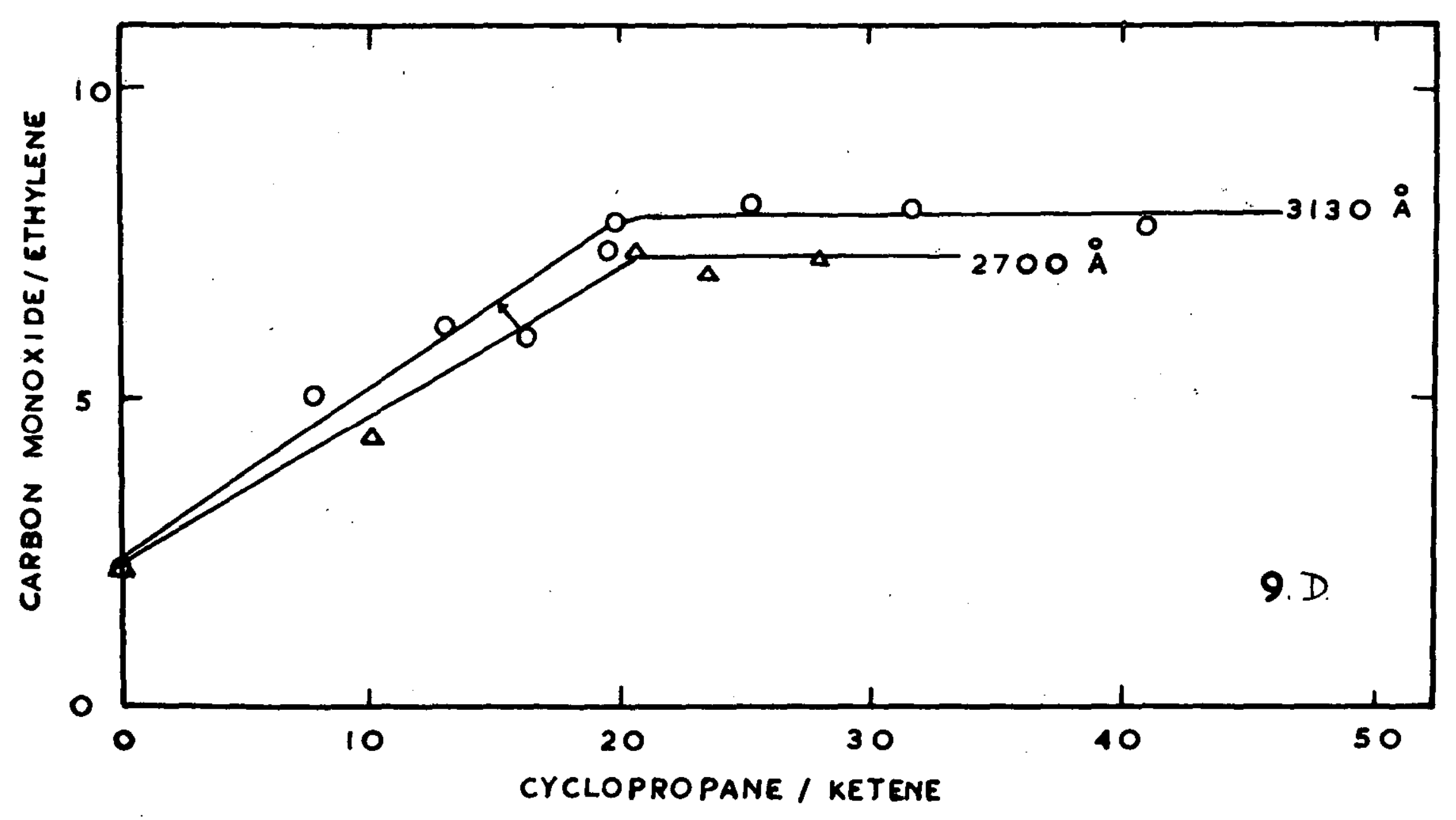


It was therefore doolded to neasuro only oarbon wonoyde and tethrieno.

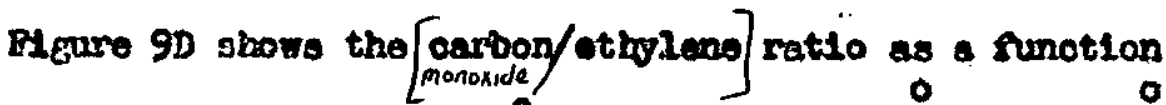
of cyclopropand $/ x$ tene rat10 at $37^{\circ} \mathrm{C}$. Both at $3130 \mathrm{~A}$ and $2700 \mathrm{~A}$ the oarbon monoxide/othyleno ratio beooute constant when the ayolopropano/ketene ratlo exceods 20 : 1. Purthor result, not showe in FIoure 9D, indiogte thot this constancy is malntalned up to eyclopropene/hytene ratios of 80/2. Tho 2infiting ralues of the carbon monoxide/etrolene ratio aro 8.0 and 7.2 at 3130 and 0 2700 A, respectively. The corresponiling propostions of tiplet wethyleno at the two ravelengthe aro therefore 14 and 268 respoctively. These values are in excellont ogreanent with those

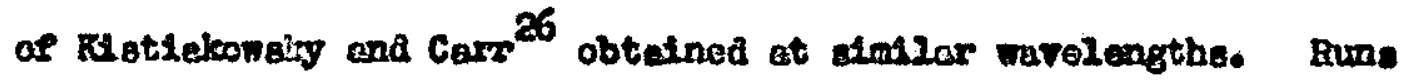
wore deno at woh ravelength with propyleno in place of avolopropane. As expeoted, no ethylene was deteoted in these experiments. It appoars that at $3150 \mathrm{~A}$, not all of the methylenes formod are singlat. Sone 245 aro triplet. This is further artaonce in apport of tho woobanter outisnca on page 55, in which interatem arosing ocours from tho highor vibrationsl levels of tho exaltad sinelet stato of keteno to form vibrationaly exoltca triplet

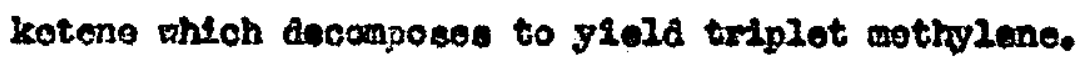
The velue of $\alpha$ at $3230 \mathrm{~A}$ and $37^{\circ} \mathrm{C}$ cen be used to corculate $\mathrm{k}_{20}+\mathrm{k}_{2 b}$. tho rato constents for decosposition from the sinclet itate. The lienling alope of tho $2 / \% \mathrm{co}(\mathrm{K})$ plot so equal to 14.9 (wole/2itro), ${ }^{-2}$ and this arvided by $\alpha$ furntshos $k_{40} / k_{20}+k_{20} \cdot k_{40}$ heo been oalculoted proviousis, (pago 52) ant henos

$$
k_{2 a}+k_{2 b}=9.77 \times 20^{9} 800^{-1}
$$


Inowing the value of $k_{20}+k_{2 b^{\circ}} \alpha$ aan be uad to celoulate $k_{30}+k_{30}$, the sun of the rate constente for interaveten arosesing to the tziplot state. Thie wa found to be $1.59 \times 10^{9} \mathrm{ee0^{-1 }}$. mon $\alpha$ is doterminod at $3660 \mathrm{~A}$, and at rarloun

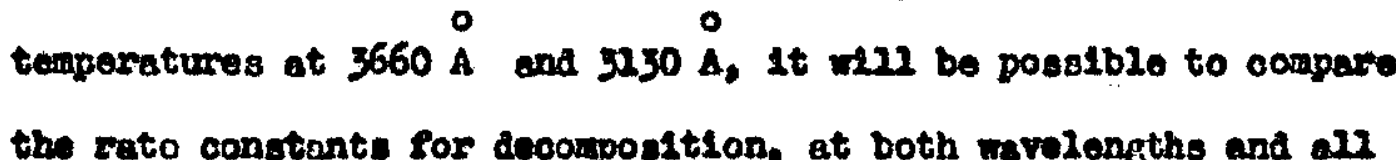
temperetures, wh the sete constants caloulated from unimolecular reaction theory. Attempts to manuro $\alpha$ at $3660 \mathrm{~A}$ in this work were fruotrated by the onsz guantitios of produots formed In the photolysis of keteno - oyclopropane alxtures. A reaction oll aurrounded by the ultravialet lemp woula increase the arount of produots, and thl together w th a more senaltive obromatocraph would enable $\alpha$ to bo determined et $3660^{\circ} \mathrm{A}$.

It would be advantageous to know the rato of hydrogen astraotion by triplet nothyzeno compared to 1 ts rete of reaction wth ketene. Tho wothod of produolng exiplet mothyleno as used by Dunoan and cretanorle 39 ight be sultable for thite purpose.

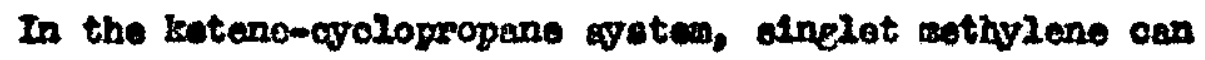
rezot wh tho $\mathrm{C}$ - $\mathrm{C}$ bond in ketene or ath the $\mathrm{C}-\mathrm{B}$ bonds of cyolopropane. The rolative rates of double bond adation ond $\mathrm{C}-\mathrm{I}$ bond insertion have been cessured in metholenomolofin watose, and tho ratio of eddition: insertion is 20-30, $1^{47}$. Aliphatio carbon-hyarogon bonde are attacked by methylene, 6-17 times alowr than carbon - carbon doublo bona ${ }^{36}$. In the botene- cjolopropano waten the carbon monodde/athyione ratio becano conctant at a colopropane/katano rotio of 20/2. Inlo inalooted that Firtually all the inelet wothlone, Pormed in the photolyst at this ratio, was recoting wth ayclopropane, and 14 can bo estimated frop this that singlet cothylene recots of th botane about enfoe as fast as 
Wth ayalopropene, or about twelve times as fast as whth one of the C - I bondo of cyolopropane, Thus the ratlo of adation: insertion observed in this aysten is withen the range found by. other workors.

The ainglet/triplet retio of nethrieno coula be deternined by poasuring the insertion products from the reaction of oinglet wothylene Ath cyolopropane. As indloated above,

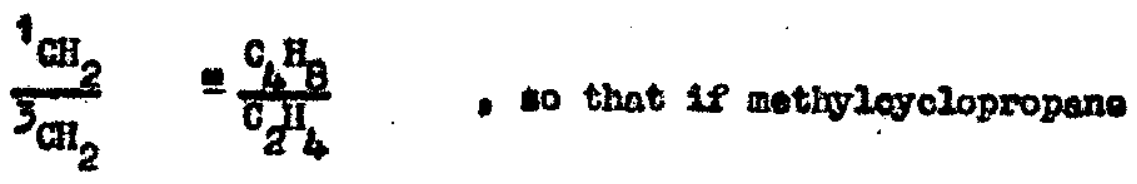
and butenes waro neasured, a well as otholone, second deternination of the sinelet/triplet ratio could be obtained. 


\section{RBYTERETCES}

2. R.G.H. Roxer sh, R.G, Crono, and O.D. Saltuaroh,

J. Chem.S00, 2535, (1953).

2. M.P. Ross and G.B.KLatLakowsib.

J.Anor.Chem. Soo.,

56. 2112, (1934).

3. R.G.E. Norresh, H.G. Crono and O.D.Saltmerah,

1b1a, 56, 1644, (2934)

4. G.B. KIstralsowsky and N.W. RosenberG,

IbId, 72, 321,(2950).

5. H.Venpee ona R. Grand,

Ann, Hin. Belce:

49. 701. (2950).

6. A.N. Btrechan and H.A. Noges Jr.,

J.Amer,Chan, 800."

76. 3258 (2955).

7. A.N. Strechan,

Ph. D. Thoo1s, Universt ty of Rochester (1954).

8. G.B. Parter and B.T. Comaly,

Can. J. Chem.,

36. $1640,(2958)$.

9. G.B. Kistiakowaky and B. Kahan,

J.Amer, Chem, S00.,

72, 2412, (2957)

10. G.B. Portar ana B.I. Conne22y,

3. Chom. Physe:

33. $81,(2960)$.

12. H.B. SLater

Proc.Roy.S00. (London). A194,212, (1948): 


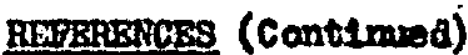

13. I. J. Kabsol,

13. G.A. Feglor Ged Gorter,

24. V.A. Noges Jr,, and I. Onger,

25. B.A. L. Anot, R.P.V. Bater and A.Ven dor Aumera.

26. घ.1.. Erey

17. G. Hereberb and J. Shooemith,

18. G.J. B1shor, A.8. EoCloan and A. D. Sniser,

19. G. Swarsenbech and $\mathrm{X}$. Lutg,

20. H. Kecho,

2. R. B. funt and D. Darlo, Jr.,
Ininotics of fiomogenoous Gás Reciotionis, (Chendoel Cetelog Company, Ino., Hew York, 1932).

3. Chem. Fuyo.. 36. 1353, (1962).

Pure App2. Cheso, 2. 462, (1964).

J.Amer. Chem, So0." 82, '3217, (1960).

2b1d, 88, 5947.(2960).

Nature, 183,1801,(1959).

J. Orge Chem. 28. 1055, (1953).

Helv, Chim. Aota., 23. $2159,(1940)$.

J.Opt. S00. Aner., 929, (1948).

J. Amer, Chen. Soo., 69\% 4425, (2947). 
RIDARFTCS (Continued).

22. W. Davis,

23. A.S. Taglor and S. Glestone

24. C. Brediey Woore and G.G. Pinentel,

25. R.N. Mzon and G.H. Intor.

26. R.W. Garr, Jre, and G.B. Ilatiekowak,

27. B.S. Rabinovitoh and H.C. Mownso,

28, A. $\pi_{Q}$ Strachen and D.F. Whornton,

29. J.1. S1mons and B.9. Babinorttoh,

30. H.M. Brw..

31. G.B. Kistlakowsky and X. Saunr, 101d, 70, 2868,(2948).

A Treatise on Pingsion Chend otiny, pase 655. (D. Van Hostrand Co. Ino. Eor Jerreg, 2942).

J. Cher. Frove. 38. $2816,(2963)$.

Trans, Dereday, 800. 62. $2406,(1966)$.

J. Finso. Ghom. 20. 218, (2966).

quert. Rov., 13, 122, (1964).

J. Payse Chuna 70. 952, (2966).

1bia, 68, 1322, (2964).

Ches. Com.

1. 260. (2965).

J. Anor, Chein, 800., 78, 5699, (1956). 


\section{REFAREACES (Cantintied)}

32. R. S. Slreil and R.C. Woodworth,

33. W.von B. Dooring and Polearzanno,

34. D.von E. Doexing and R. Frinsbaoh,

35. H. H. Frov,

36. J.A. Ball.

37. H.H. Erey.

38. S.D. Benson and M.B. Dellore,

39. R.J. Danoan ana R.J. Cretianovio,

40. B.H. Dorer and B.S. Rebinovitoh,

42. Siflo, I. Ungar, and T.A. Hojes, Je., a) J.Anárichenosog. 76. 4996. (1956).

b) 101a, 82. 3383, (1959).

$1 b 1 d, 78,5447$ (1956).

To'trehediron,

6. 24, (1959).

Proc. Roy. Soo. (Ionaion) A250, 409, (1959).

Progr. thy s. Org, Chen. 2. $1,(204)$.

J.Aner. Chime Soo.", B2. $5947,(2960)$.

Advain. Shotooboin. 2. 219, (1964).

J. Amor. Chow S00. Bj. 3593; (1962).

'. Fuy chan. 69. 1964, (1965).

J. Amor, Cham. Soo., 67. 2297; (2969). 


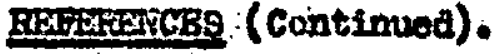

42. B.S. Rabinovitch, K. H. Ratidins and D.P. Ring.,

1bsa, $97,4960,(1965)$

43. C.HoKnight, Z.K.C, Loo, and P.S, Rowlanda., 1bid, 82, 469. (2067).

44. R.D. Cmiall and A.S.Dav1 B.,

1bia, 89, 1329,(1966).

45. B.A.DeGrare and G.B. Kiotiakowbiv.,

3. Prya. Cheme. 2. $2553,(1967)$.

46. B.,B. Cundall end A.S. Dav1s.,

Progr. Regoto Rinotios.s. A. 149, (1967).

47. H.H. BRES.

1b1a, 2, 231; (1964).

48. R.H.P. Bador and J.I. Genarosa,

Can. J. Chear.

43. 2631, (1965).

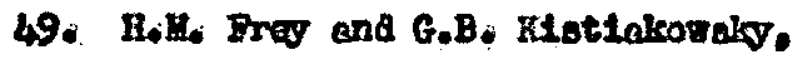

J.Amor, Chem, Soo.,

79. 6373. (1957).

50. E, H,R. Sterole, ..

"Atomito and Pros Radsoal React10ns".

2na Eastion, page 500, Relnhola Publishing Corporation, Vow York, 20540"

52. P. Bowery

J. Chem, 800 . (i) , 3, 466, (1967). 


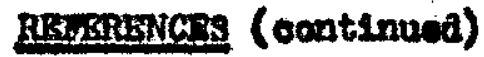

52. G.B. Porter and P. Doters

J. Phy t. Chow.e 70, 1622, (1966). 
